\title{
Comparative Nationalisms and Bibliographic Black Holes: The Case of the Turkmen of the North Caucasus
}

\author{
Kit Condill ${ }^{*}$ \\ International and Area Studies Library, University of Illinois at Urbana-Champaign, Urbana, Illinois, USA \\ *Corresponding author. Email: condill@illinois.edu
}

\begin{abstract}
The centuries-old Turkmen community of Stavropol' Krai in southern Russia, while currently numbering only about 15,000 people, is an integral part of the famously diverse ethnolinguistic landscape of the North Caucasus. To the extent that Euro-Atlantic scholars have noted the existence of this community at all, their comments have been rather cursory and dismissive, and it has been claimed that the North Caucasus Turkmen (virtually alone among the dozens of similarly small ethnic groups of the region) have never published anything in their own language. Intensive investigations in the bibliographic record (and in secondary sources in Russian, Turkish, and Turkmen) show that this is not actually the case, and that the North Caucasus Turkmen do have a modest record of Turkmen-language publishing stretching back a century or more. What are the implications of these published works for our understanding of Turkmen identity, the Turkmen diaspora, and the complicated multiethnic and multilingual environment of the North Caucasus? What does it mean when groups like the North Caucasus Turkmen are made all but invisible in Euro-Atlantic scholarship and Euro-Atlantic library collections?
\end{abstract}

Keywords: Turkmen; North Caucasus; diaspora; identity; scholarship; libraries

\section{Introduction}

For a variety of historical, geopolitical, and linguistic reasons, Turkmenistan and the Turkmen are notoriously understudied in the academic institutions of the Euro-Atlantic world. A few occasionally impressive exceptions notwithstanding, the great research library collections of North America and Western Europe are, likewise, sorely lacking in vernacular-language Turkmen materials, especially when compared to the totality of Turkmen-language publishing as reflected in the national bibliography of Turkmenistan (and especially in the works of Turkmenistan's greatest bibliographer, Almaz Ýazberdiýew). The proportion of all Turkmen-language monographs published before 1929 that are held in even a single US library, for example, does not exceed 6\%, or approximately 40 out of the 678 such monographs listed in Ýazberdiýew's excellent Soviet-era bibliography (Iazberdyev 1981). ${ }^{1}$ For Turkmen-language works published after the abandonment of Arabic script in 1928, the picture is actually slightly worse, with approximately $5.8 \%$ of the post1928 monographic works listed in the major bibliography for mid-20th-century Turkmenistan (Kuvadova, Panova, and Pirliev 1965) held in any US library. ${ }^{2}$ Of the 87 post-1960 Turkmenlanguage periodical titles listed in the authoritative source on the journals and newspapers of Soviet Turkmenistan (Nazarova 1989), US libraries hold one or more issues of only 12 , meaning that $86 \%$ of them are not held in US libraries at all. Of the approximately 600 Turkmen-language

\footnotetext{
(C) The Author(s), 2021. Published by Cambridge University Press on behalf of Association for the Study of Nationalities. This is an Open Access article, distributed under the terms of the Creative Commons Attribution licence (http://creativecommons.org/licenses/by/4.0/), which permits unrestricted re-use, distribution, and reproduction in any medium, provided the original work is properly cited.
} 
monographic works published in Turkmenistan in the early 1990s (as reflected in the monthly issues of Turkmenistanyng metbugat letopisi, 1991-), US libraries hold about 29\%. ${ }^{3}$ Since 1997 it has become extremely difficult to obtain national bibliographic publications from Turkmenistan to use as a benchmark for assessing US library holdings, but based on my years of experience working in a major US library collection, I can personally attest to the difficulty of obtaining any Turkmenlanguage materials at all during the 2000s and 2010s.

There are several valid reasons for this state of affairs, including Turkmenistan's long-standing near-inaccessibility for Euro-Atlantic scholars, librarians, and library vendors; extremely scant knowledge of the Turkmen language in North America and Western Europe, and extremely limited opportunities to learn it; the concomitant limited demand for such materials on the part of libraries and library users; and, therefore, the low priority placed on collecting Turkmen-language materials by most major Euro-Atlantic research libraries. None of this, however, should be construed as a judgment on the intrinsic interest of Turkmenistan and its history; on the intrinsic interest of Turkmen identity as a subject of study; on the intrinsic interest of literature and scholarship produced by Turkmens (in Turkmen, in Russian, and in other languages); on the intrinsic interest of the confluence of Turkmenistan's abundant natural resources, its authoritarian system of government, and the geopolitical significance of both; or (most importantly for this article) on the intrinsic interest of the Turkmen diaspora. Adrienne Edgar's Tribal Nation (2004) and Victoria Clement's Learning to Become Turkmen (2018), the two major English-language works on Turkmenistan, were both extremely well received and (based on their glowing reviews in Slavic Review [Smith 2005], Russian Review [Khalid 2019], The Journal of Modern History [Grant 2006], and elsewhere) have only whetted the Euro-Atlantic appetite for more research on this fascinating country and people.

But while the task that lies ahead for Euro-Atlantic scholars and libraries with regard to their Turkmen-related research and collections may seem straightforward based on the above (i.e., to do more), the virtually unknown publication history of the small Turkmen community of the North Caucasus raises many additional questions about the interplay of library collections and the scholarly record in the Euro-Atlantic world, and throws others into stark relief. How can our understanding of Turkmen identity ever be complete without considering how Turkmen diaspora communities think of themselves and their own identity? How can it be complete without considering how Turkmen diaspora communities are viewed inside Turkmenistan itself? Are they considered to be part of the greater Turkmen nation or not, and does the answer to that question vary depending on which diaspora community is under consideration, and on who is doing the considering? With regard to the Turkmen of the North Caucasus in particular, will we ever know the answers to these questions? Or, in time, will they become impossible to answer, because EuroAtlantic libraries never bothered to collect any North Caucasus Turkmen publications before their community was transformed beyond recognition by climate change, war, revolution, environmental disaster, or draconian government policy (all of which are rather familiar phenomena in the region)? Questions like these, and the ways in which the Turkmen of the North Caucasus bring them into particularly sharp focus, will be explored in the pages that follow.

\section{The Turkmen Diaspora and Its Publications}

The Turkmen diaspora is defined differently depending on who is doing the defining. To some, virtually the entire Turkmen diaspora lives in Iran, Afghanistan, Uzbekistan, and Tajikistan, in close proximity to the borders of Turkmenistan itself, and numbers about one million people (vs. about five million inside Turkmenistan). ${ }^{4}$ To others (including many Turkmen authors, especially those who wrote immediately following the collapse of the Soviet Union in 1991, such as Durdyev and Kadyrov [1991a, 1991b], Durdyev [1992], and Ataev [1993]), the Turkmen diaspora numbers over 20 million and also encompasses the nomadic (or formerly nomadic) Yörüks of Anatolia and the Balkans, the descendants of the Ottoman-era Turkic populations of Jordan, Syria and Iraq, and the Salars of the Ili Valley and the Qinghai province of China, for a 
geographical range of over 4,000 miles from east to west. ${ }^{5}$ As Sebastien Peyrouse puts it in his Turkmenistan: Strategies of Power, Dilemmas of Development, "According to Turkmen official data, there are about twenty-two million Turkmen in the world, or a diaspora of more than seventeen million people. More realistic studies put forward a figure of about four million for the Turkmen diaspora" (2012, 62). Ýazberdiýew himself makes a point of including so-called "Turkmen" publications from Iraq in his 1981 bibliography. ${ }^{6}$ It is not my purpose here to litigate these competing claims but rather to note that there is, in effect, a lively debate on the question of who is a Turkmen and who is not, and that this debate (in the pages of books, journals, newspapers, scholarly and pseudoscholarly websites, and, increasingly, on social media) has been going on for many decades.?

One particularly interesting (and woefully understudied) participant in this debate is the Turkmen government's own attempt to manage this question: the Dünýa Türkmenleriniň Ynsanperwer Birleşigi (DTYB), or World Turkmen Humanitarian Association. This organization has (or has had) multiple branches in Russia, Central Asia, and as many as 30 countries worldwide, and it has also held an official congress in Aşgabat every year since its founding by Saparmyrat Nyýazow Türkmenbaşy in 1991. Current Turkmen president Gurbanguly Berdimuhamedow assumed Nyýazow's position as the titular head of this organization in 2007, and, like his predecessor, he typically addresses the congress as its keynote speaker.

Officially founded to offer "assistance in arranging cooperation with independent Turkmenistan, the preservation of national traditions and customs, and the revival of the ancient original Turkmen culture," critics from the Turkmen diaspora and Turkmen political exiles characterize the entire organization as "window dressing" and a propaganda exercise (Tadzhiev 2009). A particularly scathing critique was leveled in 2002 by Boris Şyhmyradow (the former Turkmen minister of foreign affairs, then in exile in Russia) and Myrad Esenow (a longtime Turkmen dissident then working as an academic in Sweden). The pair characterizes the association as a "fake institution" and diaspora participants in the annual congresses as crooks, rogues, and impostors who "lack authority in the Turkmen diaspora, and who are not able to represent its interests in the various countries in which it exists" (Shikhmuradov and Esenov 2002). Syhmyradow himself edited the proceedings of the 1993 congress (Shykhmyradov et al. 1993), but he is likely still a political prisoner in Turkmenistan after his arrest in 2002. His personal role in the DTYB, his later criticism of it, and his subsequent imprisonment place him and the DTYB at the very center of the debate on Turkmen diaspora identity and entangle it thoroughly in the questions of Turkmen government legitimacy explored by Polese \& Horák (2015) and Denison (2009).

On the national and ethnic identity of the 15,000 Turkmen of the North Caucasus, however, there is no debate. Their migration around the northern shores of the Caspian Sea beginning in the 17 th century is documented in the historical and diplomatic record and is associated with the simultaneous arrival of the Kalmyks in the region. The first Turkmen to live west of the Volga River served as bodyguards to the Kalmyk khan Kho-Örlök (c. 1580-1644). They were followed over the next 200 years by successive groups of Turkmen emigrants from what are now Turkmenistan and western Kazakhstan (Pan'kov 1960; Avksent'ev 1996; Kurbanov 1995, 22-30, 34-35, 38-39). To Russian scholars of the 19th and early 20th centuries, they were known as the Trukhmen. In 1825, the greater part of their territories was organized into a Trukhmenskoe pristavstvo. In 1864 the future administrative and mercantile center of the North Caucasus Turkmen was established near the center of their summer pasturelands, hence its name-Letniaia Stavka (i.e., Summer Quarters or Summer Camp). The Turkmen territories were largely reorganized into a Turkmenskii raion in 1920 and then a Turkmenskii natsional'nyi raion (Turkmen National District) in 1925 (Akopian 2006, 95-96; Akopian 2009, 61; Tsutsiev 2006, 64, map 22). The district's national status was revoked sometime in the 1930s, and the district was abolished altogether in 1956. A much smaller Turkmenskii raion was reestablished in 1970. Today the North Caucasus Turkmen live in about 20 villages mostly concentrated in the Turkmenskii and Neftekumskii raions of Stavropol' Krai (see fig. 1), with a historically related population living about 300 miles to the northeast near Astrakhan in the villages of Funtovo-1, Funtovo-2, and Atal. ${ }^{8}$ 


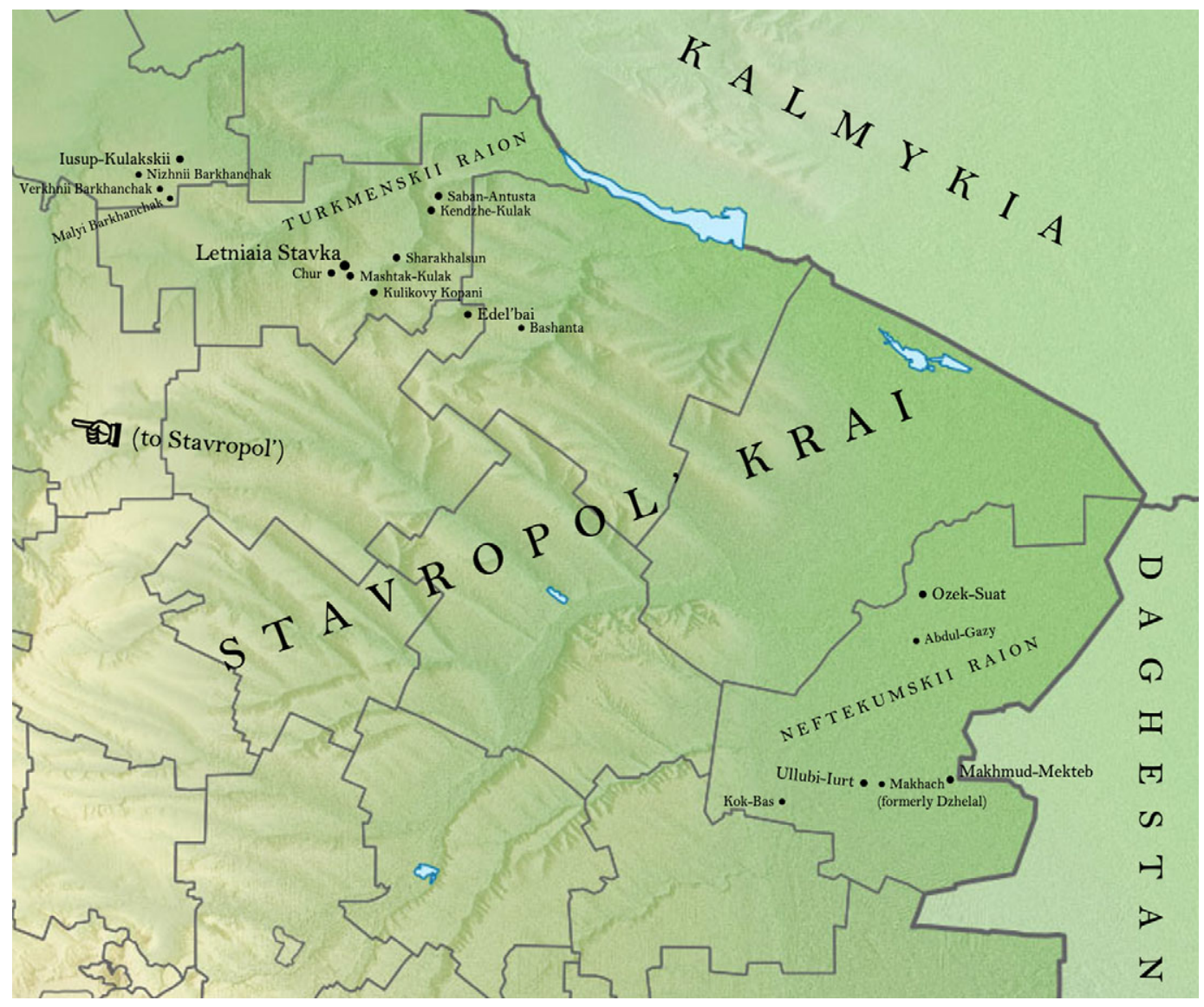

Figure 1. Map of the Turkmen villages of Stavropol' Krai, by the author. (Derived from Виктор B, "Relief Map of Stavropol Krai,” Wikipedia Commons, https://commons.wikimedia.org/wiki/File:Relief_Map_of_Stavropol_Krai.jpg.)

As dire as the situation may be regarding Turkmen-language publications from Turkmenistan in Euro-Atlantic libraries (as described above), for Turkmen diaspora publications it is even worse. As a rough indicator of the scale of the problem, as of February 2020 there are 6,522 titles with the primary language code "tuk" (i.e., Turkmen) in WorldCat. ${ }^{9}$ (Many of these are duplicate records for the same book or journal or newspaper, so the true total of Turkmen-language titles held in the over 70,000 [primarily Euro-Atlantic] library collections represented in WorldCat may be closer to 4,000.) ${ }^{10}$ Of these, about $87 \%$ were published in Aşgabat (also represented in WorldCat as Ashgabat, Ashkhabad, Ašchabad, Poltoratsk, ${ }^{11}$ Askhabad, Ashabat, Ashabad, Ashhabat, Asxabad, Acgabat, ${ }^{12}$ Asrabat [sic], Asgbad [sic], etc.), leaving about 850 records (some of which, as noted above, are duplicate records for the same item). Of these, about 165 are for items published in other towns and cities within the current borders of Turkmenistan, and a further 110 were published in Tashkent, Moscow, or Leningrad/St. Petersburg. Before 1929, these latter tended to be published on behalf of Turkmen institutions that lacked printing presses with Arabic movable type, and after 1929, they tended to be major Turkmen-Russian dictionaries or large-format multilingual works on Turkmen art or architecture.

That leaves approximately 575 catalog records, or $9 \%$ of the total, to account for all other Turkmen-language publications. Approximately 250 of these are language-learning materials, museum exhibition catalogues, or recordings of Turkmen music published in Western Europe or North America. Approximately $30 \%$ of the remainder seem to have been coded erroneously as 
Turkmen-language materials, ${ }^{13}$ leaving about 225. Approximately 60 of these were published in Istanbul or Ankara, but rather than being productions of the pre-1917 Turkmen diaspora (which, in the context of modern Turkey, is usually identified with the seminomadic Yörük population of eastern Anatolia), most of them seem to be part of the general Turkish enthusiasm for the literatures of Turkic peoples from all over Eurasia. ${ }^{14}$ That leaves approximately 165 catalog records in WorldCat to account for virtually the entire publication history of the Turkmen diaspora, and many of these, as noted above, are duplicate records for the same items. A few dozen of these are for Iraqi publications coded as Turkmen, many of them published before and (especially) after the 1969-1976 window included in Iazberdyev (1981), and a few dozen more are for Iranian publications, many of them from cities near the Iranian-Turkmen border.

As for vernacular-language publications emanating from the Turkmen community of the North Caucasus, it appears that out of all of WorldCat's four billion catalog records, there is exactly one, for a single copy of a 75-page book of poetry published in Aşgabat by a North Caucasus Turkmen in 1994. The details regarding this publication, along with the others unearthed in the course of my research, will be provided later in this article. First, however, the place (or lack thereof) of the Turkmen diaspora in Euro-Atlantic scholarship (especially in contrast to its treatment in the Russian, Turkish, and Turkmen scholarly literature) must be considered.

\section{The Invisible Diaspora of a Nearly Invisible Country}

At least partly because of the almost complete absence of materials in Euro-Atlantic library collections, no Euro-Atlantic scholar in any discipline seems to have engaged with the North Caucasus Turkmen in a sustained or serious way. Their existence has been acknowledged, at least, in the works of Ronald Wixman, who mentions them in passing several times in his Language Aspects of Ethnic Patterns and Processes in the North Caucasus $(1980,66,88,95,111)$. The only substantive statement Wixman makes about the North Caucasus Turkmen is in his The Peoples of the USSR: An Ethnographic Handbook (1984), and unfortunately it is misleading on several points. His entry on the North Caucasus Turkmen (i.e., the Trukhmen, as noted above) reads as follows:

TRUKHMEN. Oth[er] des[ignation] Trukhmen (Turkmen) of Stavropol.... The Trukhmen are the descendants of Turkmen from the Mangyshlak Peninsula region of Turkmenistan ${ }^{15}$ who settled in the Nogai steppe in the North Caucasus in the 17th cent[ury]. They have been strongly influenced by the Nogai in that region, and in the past were being assimilated by them .... The dialect of Turkmen spoken by them has been strongly influenced by Nogai and Russian. It differs greatly from the Turkmen dialects of Turkmenistan. The Trukhmen use the Nogai and Russian literary languages (not Turkmen). Population 4,533 (1926). In the 1926 census the Trukhmen were listed as Turkmen. The Trukhmen are being assimilated by the Nogai. They are Sunni Moslem in religion. They live, primarily, in Stavropol Krai in the steppe region of the North Caucasus. (Wixman 1984, 194; italics added for emphasis) ${ }^{16}$

As will be shown below, although the Turkmen of the North Caucasus certainly did write and publish in Russian, and although it is plausible (given the several decades of Nogai-language primary school education to which they were subjected; see Brusina [2008, 34] and Yliasov $[1994,3])$ that they also wrote and published in Nogai, they also wrote and published works in their native language, and as of 2020 they seem to have rather successfully resisted assimilation into the Nogai ethnos. Yet the way they are treated in subsequent Euro-Atlantic scholarship suggests that Wixman's dismissive comments reflect some kind of inadvertent consensus, namely, that the North Caucasus Turkmen have never published anything and are therefore not worthy of serious study. As with the monographs discussed below, it is ultimately not my intention to criticize Wixman's work. Certainly the compilation and interpretation of the rather remarkable amount of information Wixman communicates in these two monographs would be difficult (and very 
welcome) in any epoch, but particularly in the late 1970s and early 1980s, when Euro-Atlantic knowledge of the North Caucasus and many of the Soviet Union's smaller ethnic groups was minimal.

Among the few English-language scholarly monographs to cover Turkmenistan in a substantive fashion is Peyrouse (2012), mentioned above. Atypically, Peyrouse does include two pages devoted to the Turkmen diaspora, these pages do actually mention the Turkmen of the North Caucasus, and (nearly uniquely in all of Euro-Atlantic scholarship) Peyrouse actually cites a Russian-language source on the North Caucasus Turkmen $(2012,62-63) .{ }^{17}$ In contrast, the North Caucasus Turkmen appear only once in the two main English-language works on Turkmen national identity mentioned above: Adrienne Edgar's Tribal Nation: The Making of Soviet Turkmenistan and Victoria Clement's Learning to Become Turkmen: Literacy, Language and Power, 1914-2014. ${ }^{18}$ It would be disingenuous, however, to criticize either of them for this lack of attention; Edgar and Clement write about the formation of national identity within Turkmenistan's current borders, not elsewhere, and without Edgar (2004), Clement (2018), Peyrouse (2012), and at most a handful of other works, there would be no book-length scholarly treatments of any aspect of Turkmen identity or Turkmen history and culture in the English language. Clement does mention the fact that the purges of the 1930s accused the Turkmen diaspora in Iran of being in league with British imperialists $(2018,74)$, and Edgar devotes a fair amount of space to the emigration to Iran and Afghanistan of Turkmen families fleeing early-Soviet economic, political, and cultural disruptions (2004, 213-220), although the diaspora communities there (and their experience of Turkmen identity) are not explored any further. The presence of an unknown number of early- to mid-20th-century Soviet émigrés in geographically-contiguous diaspora communities would seem to add to the inherent scholarly interest of those communities, but the border areas of Iran and Afghanistan have been difficult and dangerous regions for most Euro-Atlantic scholars to conduct research in for several decades now. ${ }^{19}$

The other major English-language scholarly monograph on Turkmenistan is S. Peter Poullada's Russian-Turkmen Encounters: The Caspian Frontier before the Great Game (2018), which, despite its unrelenting focus on the role of various Turkmen tribes in relations among the Russians, Kalmyks, and Uzbeks at the exact time that Turkmen migration to the North Caucasus was occurring, and even noting that "by the mid-1640s a mass migration out of Mangyshlak was under way" (46), makes no mention of the North Caucasus Turkmen. Again, it is not my purpose to criticize the few (and therefore very welcome) English-language scholarly monographs that wrestle with the history, culture, and national identity of the Turkmen; I am merely pointing out that, not surprisingly, those few English-language scholarly monographs on Turkmenistan that do exist almost completely ignore the existence of Turkmen diaspora populations that might shed light on the nature of Turkmen-ness in the modern world-and in particular, they ignore the nearly 400-year-old Turkmen community of the North Caucasus.

To consider this state of affairs from another angle, English-language works about the North Caucasus or the Russian imperial frontier in general are equally silent (or nearly so) on the Turkmen of the North Caucasus. There are, for example, two entries for "Turkmen(s)" in the index to Marie Bennigsen Broxup's The North Caucasus Barrier: The Russian Advance towards the Muslim World, but one of them refers to the infamous Russian massacre of the Turkmen at Gökdepe near Aşgabat in 1881 (Broxup 1992, 9), and the other refers to the inability of the Soviet Union to persuade the Turkmen of Afghanistan to join the Soviet cause during the Soviet-Afghan War of 1979-1989 (23). The North Caucasus Turkmen receive two sentences in Cambridge's 898-page The Caucasus: A History $(2013,237)$, and award-winning historian Willard Sunderland devotes three sentences to the settling of Russian internal migrants on Nogai and North Caucasus Turkmen land in the late 19th century in his Taming the Wild Field (2004, 193-194). ${ }^{20}$ (In a work that covers Russian colonization across the entire western Eurasian steppe beginning in the 9th century, however, this could be considered an appropriate level of attention.) There is no mention of the Turkmen in Alex Marshall's otherwise-excellent account of the history of the North Caucasus since the 19th century 
(2010). And finally, despite the strong focus on Stavropol' Krai in Andrew Foxall's Ethnic Relations in Post-Soviet Russia: Russians and Non-Russians in the North Caucasus (2015), the North Caucasus Turkmen do not appear in the index, and are only mentioned in passing as one of the region's minority populations $(60,62-63,67)$.

As far as German- and French-language monographic works and dissertations on Turkmenistan are concerned, their field of inquiry tends to be even more focused on Turkmenistan itself, and, accordingly, the North Caucasus Turkmen do not, to the best of my knowledge, make an appearance (e.g., Fénot and Gintrac 2005; Rousselot 2015; Ashirova 2009; Maghsoudi 1987). German and French works that focus on the North Caucasus, like their English counterparts, also treat the region's Turkmen population cursorily or not at all; the North Caucasus Turkmen are not, for example, mentioned anywhere in Jeronim Perović's 544-page Der Nordkaukasus unter russischer Herrschaft (2015), apart from their inclusion on two of the maps at the end of the book (496, Karte 2, 501, Karte 7). Even in Ingeborg Baldauf s 782-page Schriftreform und Schriftwechsel bei den muslimischen Russland- und Sowjettürken (1850-1937) (1993), the North Caucasus Turkmen are nowhere to be found, despite a whole chapter on alphabet reform among the neighboring Nogais, Karachais, Balkars, and Kumyks (310-315), several pages on the development of alphabets for non-Turkmen peoples within Turkmenistan and for Turkmen groups outside Turkmenistan (561-563), and a detailed chronology of Turkmen orthographic reforms (699-702).

The same appears to be true of the Euro-Atlantic periodical literature. The Turkmen of the North Caucasus are occasionally mentioned, but they never appear as the object of scholarly study in their own right. For example, while the results of keyword searches in JSTOR for articles and book chapters that contain both the word turkmen and the word caucasus (1,240 results), turkmen and stavropol (68 results), or turkmen and kaukasus (56 results) are encouraging at first glance, upon further examination it emerges that almost none of these have anything to do with the Turkmen of the North Caucasus. Of those that do, the following examples are typical: one line in a 38-page article pointing out that the Nogai and North Caucasus Turkmen belong to the Hanafi school of Islamic jurisprudence, as opposed to their Shafi'i neighbors to the south in Daghestan (Malashenko and Nuritova 2009, 345); one line in a 37-page article describing the harassment of Russian peasant migrants to the North Caucasus by "Kalmyk, Nogai and Turkmen nomads" (Seregny 2001, 93); one mention of the migration of Mangyshlak Turkmen to the North Caucasus in a footnote in a 33-page article (Bregel 1981, 18n33). As a more recent example, Allen Frank's (2020) article on literacy, education, and identity among the Turkmen makes some interesting arguments about pre-1917 Turkmen identity, but he makes no mention whatsoever of Turkmen communities in Iran, Afghanistan, the North Caucasus, or anywhere else in the diaspora. ${ }^{21}$ Finally, the Index Islamicus database contains entries for 1,703 articles having to do with Turkmenistan and the Turkmen, but if any of them make any mention of the Turkmen of the North Caucasus, it is not immediately apparent.

Even the searchable full text of the two million English-language dissertations digitized in ProQuest's Dissertations and Theses database yields only a handful of references to the North Caucasus Turkmen. Sean Pollock quotes a passage from the famous botanist and traveler Peter Pallas' account of traversing the North Caucasus Turkmen lands in 1793 (2006, 63-64); Aaron Michaelson mentions the efforts of the Russian Orthodox Missionary Society among the North Caucasus Turkmen in the late 19th century (1999, 228-229, 343-345); and Charles Reiss expends a few lines on one of the waves of Turkmen migration to the North Caucasus in the 18th century $(1983,297) .{ }^{22}$ But as of February 2020, not a single full-text-searchable dissertation in the database appears to do more than touch on the North Caucasus Turkmen in passing.

Despite appearances, it is not my intention to belabor the failings of Euro-Atlantic libraries and scholarship to the point that the reader thinks I am personally offended by this state of affairs. Rather, I think it is important to establish a clear and conclusive picture of the status of marginalized groups and their publications in the Euro-Atlantic world so that remedial actions can be taken, not 
only with regard to the Turkmen diaspora but also with regard to diasporas and marginalized groups all over the world.

Furthermore, this rather lengthy survey of the near-total absence of the North Caucasus Turkmen from Euro-Atlantic scholarship will be contrasted later in the article with the much better coverage of this group in the Russian, Turkish, and Turkmen scholarly literature. That literature has been essential in illuminating the publication history of the North Caucasus Turkmen themselves. There is also the question of whether even the best-intentioned EuroAtlantic library could have actually acquired North Caucasus Turkmen publications at any point in the last 100 years, or whether this could be accomplished today. Certainly, vendors of materials from Eurasia could be forgiven for concluding that there was not much of a market for North Caucasus Turkmen materials in Euro-Atlantic libraries and that there was not much profit to be made on them in any case. But Euro-Atlantic libraries have nevertheless managed to end up with all manner of unlikely items in their collections through working with vendors, soliciting and accepting donations, and taking matters into their own hands through buying trips. There is no reason why North Caucasus Turkmen publications could not benefit from the same combination of determination and luck. If Princeton can acquire manuscripts from the personal library of Imam Shamil, ${ }^{23}$ Stanford's Hoover Institution can acquire rare newspapers from all over (what would become) the Soviet Union during the Russian Revolution and Civil War (Maichel 1966), the Library of Congress can acquire the entire collection of the Siberian bibliophile Gennadii Vasil'evich Iudin (Dash 2008; Kasinec 2008; Leich 2008), the University of Illinois at UrbanaChampaign can acquire virtually the entire national bibliography of Uzbekistan in digital form, ${ }^{24}$ the British Library can acquire over 1,000 periodicals in dozens of Turkic languages (Waley 1993), and two dozen libraries in North America and Western Europe can acquire a microfilm set of 6,000 early-20th-century Russian newspapers that were only in existence for a single day (Russian National Library 1994), then surely some library somewhere in the Euro-Atlantic world can make a point of collecting North Caucasus Turkmen materials, while others focus on other similarly marginalized and ignored groups. And as will be seen below, Euro-Atlantic scholars have barely scratched the surface of the massive trove of primary-source material contained in the thousands of newspapers published in the Russian Empire, the Russian Federation, and, especially, the Soviet Union.

\section{Publications of (and on) the North Caucasus Turkmen}

The standard bibliographic source for Soviet-era newspapers is the aptly named Gazety SSSR, which boasts 12,875 individual entries for every national, regional, local, and military newspaper whose existence was known to the compilers in the late Soviet era (Episkoposov 1970-1984). It contains entries for 200 different newspapers filed under the Russian title Leninskoe znamia (The Leninist Banner), 12 entries for newspapers filed under the Russian title Znamia leninizma (The Banner of Leninism), and 51 entries for newspapers filed under the Russian title Znamia Lenina (Lenin's Banner). Among these latter are a Lenina bairaghy published in Azerbaijani in the Daghestani city of Derbent beginning in 1920 (2:426, entry no. 4511), a Stsiah Lenina published in Belarusian in the village of Svetilovichi in the Homel region of Belarus' from 1935 to 1956 (2:431, entry no. 4533), and a Sztandar Lenina published for the Polish-speaking community of Širvintos, Lithuania, from 1950 to 1957 (2:433, entry no. 4546). Hidden among this cluster of Lenin's Banners it is also possible-via looking up "Letniaia Stavka" in the geographical index of places of publication-to find one from the Turkmenskii raion of Stavropol' Krai in the North Caucasus, and, buried in the fine print of the entry, to learn that this newspaper included Turkmen-language content in 1935, 1936, 1940, and possibly earlier in the 1930s as well (2:429, entry no. 4522). Its Turkmen title was Lenin baýdagy, or Lenin baidagy in its transliterated Cyrillic guise, and to the best of my knowledge, no Euro-Atlantic library possesses so much as a single issue of it in any format. Yet in and of itself, Lenin baýdagy's presence in the most authoritative bibliography of Soviet-era newspapers not only disproves 


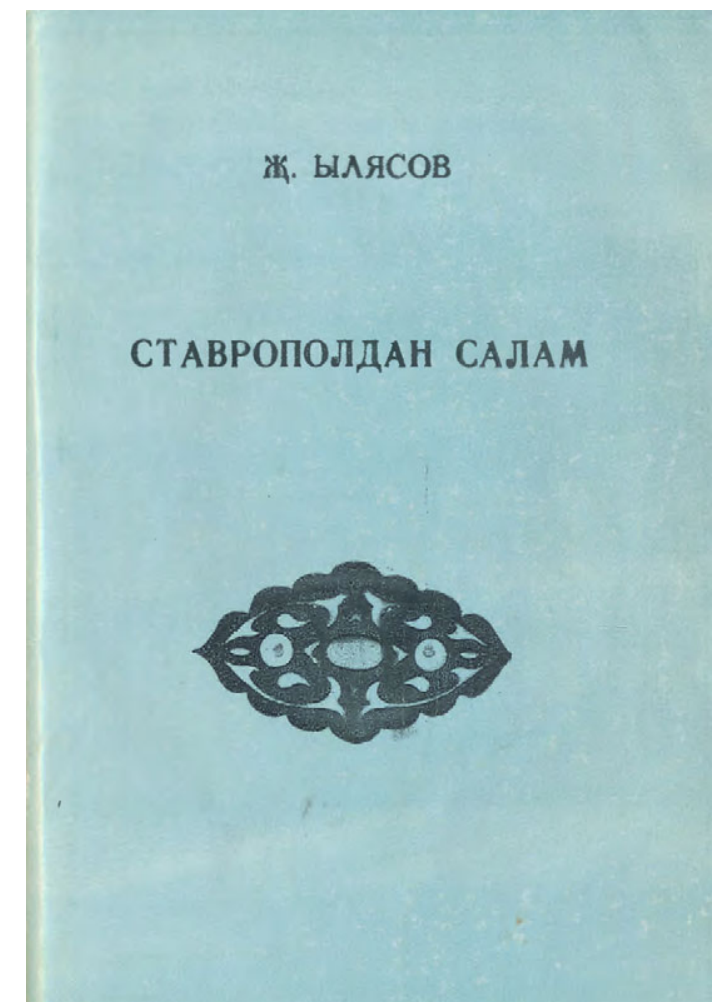

Figure 2. The cover of Jumahaset Ylýasow's Stavropoldan salam (Hello from Stavropol'), published in Aşgabat in 1994.

Wixman's assertion, but also makes the prospect of studying the North Caucasus Turkmen using their own published works from the past 85 years or more much less dubious.

Further evidence along these lines is provided by Güneş (The Sun), another Turkmen-language newspaper published in Letniaia Stavka in the 1990s. ${ }^{25}$ Although its existence is attested to in numerous sources, it is a bibliographic ghost, absent from the usual Soviet and Russian newspaper bibliographies, lacking any kind of online presence (whether current or retrospective), and, like Lenin baýdagy before it, completely absent from any known Euro-Atlantic library collection. Some of the most detailed information on Güneş comes from a volume of poetry published in Aşgabat in 1994 with the tantalizing title Stavropoldan salam (Hello from Stavropol; see fig. 2). The foreword to this volume explains that the poet, Jumahaset Ylýasow, is a Turkmen from the village of Ozek-Suat in the Neftekumskii District of Stavropol' Krai who grew up learning Nogai and Russian in local schools, but taught himself literary Turkmen later in life, and made a point of teaching it to his children as well. His son, Jepbar Ylýasow, was serving as the editor of Güneş as of 1994 (Yliasov 1994, 3-4). The elder Ylýasow was also involved in the compilation of a book of North Caucasus Turkmen proverbs and sayings published by the Turkmen Academy of Sciences in Aşgabat in 1982 (Veliev and Yliasov 1982). ${ }^{26}$

One of the best accounts of North Caucasus Turkmen culture in the 20th century is Sapar Kürenow's (1962) Stavropol' Turkmenleri khem-de olaryng medeni bailygy (The Stavropol' Turkmen and their cultural riches). This volume is held at only five Euro-Atlantic libraries (and none in the USA), but the 1995 Turkish-language version (Kürenov 1995) is more widely available. In it, Kürenow mentions the existence of a three-act Turkmen-language play published "privately" (özbaşdak/müstakil) ${ }^{27}$ in the North Caucasus in 1926 (Kürenov 1995, 76.). While this particular edition of the play has thus far proven impossible to verify bibliographically, Kürenow's claim does 


\begin{tabular}{|c|c|c|c|c|}
\hline Source & $\begin{array}{c}\text { Title } \\
\text { (as it appeared in } \\
\text { this source) }\end{array}$ & $\begin{array}{c}\text { Latin-Script } \\
\text { Version of } \\
\text { Cyrillic/Arabic- } \\
\text { Script Title } \\
\text { (using Library of } \\
\text { Congress trans- } \\
\text { literation where } \\
\text { possible) }\end{array}$ & $\begin{array}{l}\text { Authors/Editors/Compilers } \\
\text { (as listed in this source) }\end{array}$ & $\begin{array}{l}\text { Latin-Script Version of } \\
\text { Authors/Editors/Compilers as } \\
\text { Listed in This Source (using } \\
\text { Library of Congress transliteration } \\
\text { where possible) }\end{array}$ \\
\hline $\begin{array}{l}\text { Iazberdyev (1981, 192-193, entry no. } \\
546)\end{array}$ & $\begin{array}{l}\text { Гыз берув: } \\
3 \text { пердеде }\end{array}$ & $\begin{array}{l}\text { Gyz beruv: } 3 \\
\text { perdede }\end{array}$ & $\begin{array}{l}\text { Х. Н. Жуманиязов ве С. } \\
\text { Арифуллин. редакциясында }\end{array}$ & $\begin{array}{l}\text { Kh. N. Jumaniiazov ve } S \text {. } \\
\text { Arifullin. redaktsiiasynda }\end{array}$ \\
\hline $\begin{array}{l}\text { Kuvadova, Panova \& Pirliev (1965, } \\
\text { 582, entry no. 5584) }\end{array}$ & $\begin{array}{c}\text { Гыз беру: } 3 \\
\text { гөрнүшли } \\
\text { пьеса }\end{array}$ & $\begin{array}{l}\text { Gyz beru: } 3 \\
\text { górnúshli } \\
\text { p'esa }\end{array}$ & $\begin{array}{l}\text { Дүзүжилер: Х. Н. } \\
\text { Жуманыязов, С. Арифуллин, } \\
\text { А. Фирекейиф ве башгалар }\end{array}$ & $\begin{array}{l}\text { Duzujiler: Kh. N. } \\
\text { Jumanyiazov, S. Arifullin, } \\
\text { A. Firekeiif ve bashgalar }\end{array}$ \\
\hline $\begin{array}{l}\text { Knizhnaia Palata RSFSR }(1928,74 \text {, } \\
\text { entry no. 1482) }\end{array}$ & قزي به رده رده ده & $\begin{array}{l}\text { Qyz beruv: } \\
\text { uch } \\
\text { perdede }\end{array}$ & 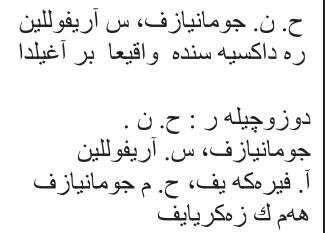 & $\begin{array}{l}\text { H. N. Jumaniyazof, S. Arifullin } \\
\text { redaksiyesinde vaqigha bir aghilda } \\
\\
\text { Duzuchiler: H. N. } \\
\text { Jumaniyazof, S. Arifullin, } \\
\text { A. Firekeyef, H. M. Jumaniyazof } \\
\text { hem K. Zekriyayef }\end{array}$ \\
\hline $\begin{array}{l}\text { Rossiiskaia Natsional'naia Biblioteka } \\
(1998 \text { c), fiche } 31\end{array}$ & قز برده برد ده بره & $\begin{array}{l}\text { Qyz beruv: } \\
\text { uch perdede }\end{array}$ & جومانيازف ح ن & Jumaniyazof, $\mathrm{H} \mathrm{N}$ \\
\hline Allworth (1971, 191, entry no. 2001) & $\begin{array}{l}\text { Qiz bäro. } \\
\text { Och pärdädä } \\
\text { oaqi'`a bir } \\
\text { aghelda. }\end{array}$ & -- & [none $]$ & -- \\
\hline
\end{tabular}

Figure 3. The 1928 Moscow edition of Hajynazar Jumanyýazow’s play Gyz beruw as represented in various bibliographic sources

lend credence to the idea that during the late 1920s, when virtually every other ethnic group in the North Caucasus was experimenting with new alphabets, engaging in massive literacy campaigns, and publishing original vernacular-language works and translations of Russian-language works in all genres and formats, the North Caucasus Turkmen, in their newly minted Turkmen National District, were doing the same. Lending more credence to this idea is the fact that the same play was (re)published in Moscow in 1928, as attested in no less than five contemporaneous and retrospective bibliographies.

The multiple guises in which this play appears in these bibliographies underscores the general difficulty of tracking down North Caucasus Turkmen publications. Originally, of course, it was published in Arabic script, but it is only in the last 10-15 years that online library catalogs have been able to display non-Roman scripts correctly, and simply copying the Arabic script into a EuroAtlantic library catalog would unnecessarily cut this play off from scholars and other library users and staff who can read a Turkic language-or who could simply understand what this item is by looking at a catalog record-but cannot read Arabic script. In other words, the conversion (or, more precisely, the transliteration) of the original Arabic-script information into Latin script is an important part of making this work accessible to scholars.

And yet as of 2020, there is still no standard Euro-Atlantic system for transliterating Arabicscript Turkmen into Latin characters, nor can experts, even in Turkmenistan itself, agree on how to read the original Arabic script in the first place. Ýazberdiýew gives the original Arabic-script title as ق ق but problems arise when various attempts to transliterate it into Cyrillic and Latin script are made (see figure 3 ).

The bottom row of this table is of particular interest, since the source cited (Edward Allworth's Nationalities of the Soviet East: Publications and Writing Systems; A Bibliographical Directory and Transliteration Tables for Iranian- and Turkic-Language Publications, 1818-1945, Located in 
U.S. Libraries [1971]) is, as the title indicates, based on items that are actually held in US libraries and that, therefore, are theoretically available to Euro-Atlantic scholars. Allworth's transliteration, however, is the worst of the five, seemingly suffering from the conviction that the Arabic-script letter "و" should always be transliterated as "o," when it just as commonly stands for "w," "v", "u", "ü", or "ö." In any case, the sum total of Euro-Atlantic holdings of publications that can be attributed to the Turkmen of the North Caucasus appears to be two: one copy of Stavropoldan salam, held at the Library of Congress, and the New York Public Library's single copy of Gyz beruw, which, despite being acquired nearly 100 years ago, has still not been added to their online catalog as of February 2020. ${ }^{28}$

Given the difficulty of identifying and locating many of the publications listed above, it is challenging to estimate the full extent of North Caucasus Turkmen publishing activity, but there are indications that more materials exist. In his article on the North Caucasus Turkmen in the 21-volume encyclopedia Türkler, Ali Duymaz mentions a certain Gurban Hajymuhammedow (Hacimuhammedov) (1894-) who was active as poet during the Soviet era, as well as the existence of a four-act play by a Murtaza Jumanyýazow (Cumanıyazov) (Duymaz 2002, 924). ${ }^{29}$ Ol'ga Brusina's Turkmeny Iuga Rossii (2016a, 186-187) includes references to the currently active folk poet Ş. U. Taganyazow (Sh. U. Tagan'iazov), to the local Turkmen cultural organization Vatan, and to other signs of potential publishing activity. Brusina also includes information on the Astrakhan Turkmen farther to the northeast. Brusina (2016b, 471, 491-492) also mentions a Dzhumaset Il'iasov, perhaps a relative of the publisher of Güneş and of the author of Stavropoldan salam, who was gathering folklore, translating Arabic poetry into Turkmen, writing his own poetry, and attempting to develop a literary language based on the North Caucasus dialect of Turkmen in the mid-2000s.

Logical next steps in identifying additional North Caucasus Turkmen publications would include fieldwork in Stavropol' Krai, as well as a thorough investigation of what is likely the largest collection of Turkmen-language materials currently available to Euro-Atlantic scholars: the Turkmen collection of the Department of the Literature of the Nationalities of the former Soviet Union at the Russian National Library (RNL) in St. Petersburg. The RNL's entire card catalog of its Turkmenlanguage holdings (numbering approximately 20,000 items in all) was duplicated on microfiche in 1998, and these microfiches are held at four US libraries, ${ }^{30}$ giving Euro-Atlantic scholars the opportunity to attempt to identify North Caucasus Turkmen publications among the RNL's excellent holdings (among other, less specialized pursuits) even before they travel to St. Petersburg.

Tracing the complete publishing history of the North Caucasus Turkmen, then, is still a bit out of reach. In the meantime, my argument is not that the handful of published North Caucasus Turkmen works described above are exceptionally valuable, or that they amount to some kind of significant corpus of primary sources; rather, the mere fact that these sources exist at all is significant. If, with a bit of determination and bibliographic expertise, primary-source publications for a group as overlooked and ignored as the Turkmen of the North Caucasus can be found, then the work that remains to be done (and that can be done) by Euro-Atlantic scholars and librarians on peoples throughout the Caucasus, Central Asia, and beyond must be massive indeed. Even for the 15,000 Turkmen of the Russian Federation, there are sources-and said sources can, with a bit of luck and know-how, be identified via secondary works and bibliographies held in Euro-Atlantic libraries, before having to contact local scholars, authors or librarians or traveling to the region in person.

As for the intrinsic value of these few North Caucasus Turkmen sources, it must be said that perhaps Gyz beruw and other dramatic works from the 1920s, if any, are puerile and derivative. Perhaps the Turkmen-language articles in Lenin baýdagy during the 1930s consist of stultifying propaganda or are simply reprinted from the newspapers of Turkmenistan. Perhaps Güneş is full of bad poetry, wedding announcements, and speculations about the weather. But with (almost certainly) no more than two works ever published by any North Caucasus Turkmen held in any library in the Euro-Atlantic world (and each of those existing in only one copy), and (almost 
certainly) no engagement with any work ever published by any North Caucasus Turkmen anywhere in the gigantic corpus of Euro-Atlantic scholarship, as of 2020 we still have no idea what these sources contain. And even if, for example, the articles in Lenin baýdagy consist of nothing but reprints from Aşgabat newspapers, Euro-Atlantic library holdings of pre-WWII Turkmen newspapers are none too strong in any case, so a series of articles that were reprinted in the North Caucasus would be most welcome. Of the 61 regional and local newspapers described in great detail by Nazarova (1989, 90-288), for example, precisely zero are held at any library in Western Europe or North America. The choice of which articles were reprinted for a North Caucasus audience is also of potential scholarly interest, as well as, for linguists and scholars of language reform, the lexicon and orthography used in the text itself. The same is true for other pre-WWII publications such as Gyz beruw, even if it makes for mediocre theatre, and even for Güneş, despite the fact that it may have little to say on the major issues of the day.

Although Wixman's contention that the North Caucasus Turkmen wrote only in Russian and Nogai is no longer tenable, some consideration should also be given to publications by North Caucasus Turkmen in other languages. Chief among these are the Russian-language works of Mahmyt Tumaýylow (Mahmut Tumailov, Makhmud Tumailov), who was born in Malyi Barkhanchak in 1902 and died in Magadan in 1937, having served as a delegate to the 1920 Baku Congress of the Peoples of the East, as the finance commissar for the Turkmen SSR, and as a declared member of the Trotskyist opposition in the mid-1920s, while also completing a monograph on the North Caucasus Turkmen, which was confiscated by the NKVD. ${ }^{31}$ Although this monograph was written in Russian rather than Turkmen, it is likely one of the most substantial and most interesting works ever produced by a Turkmen native of the North Caucasus.

Other substantial works on the North Caucasus Turkmen by Tumaýylow's coethnics in Turkmenistan itself, and by interested scholars in Russia and in Turkey, are relatively plentiful, as demonstrated by the many Russian-, Turkmen-, and Turkish-language sources cited above. Sapar Kürenow is one of the most prolific Turkmen scholars on the subject of his coethnics in the North Caucasus. Interested Turkish scholars include the abovementioned Ali Duymaz (2015), Sema Aslan Demir (2015), and Savaş Şahin (2015), all of whom contributed to the section on the North Caucasus Turkmen in a special issue of Yeni Türkiye covering the Turkic peoples of the North Caucasus. Prominent Russian scholars of the North Caucasus Turkmen include A. V. Kurbanov, a fellow at the St. Petersburg branch of the Russian Academy of Sciences' Institute of Ethnography \& Anthropology (IEA RAN), who wrote several works about the North Caucasus Turkmen in the 1990s, most notably his 237-page monograph Stavropol'skie turkmeny (1995). In the 2000s and 2010s, the primary scholar writing in Russian about the North Caucasus Turkmen was Ol'ga Brusina, a fellow at the main branch of IEA RAN in Moscow, several of whose works have already been cited above (Brusina 2008, 2016a, 2016b).

The Turkmen of the North Caucasus also attracted the attention of several Russian scholars in the early 20th century, most spectacularly Ivan L'vovich Shcheglov, whose four-volume treatise on the Turkmen and Nogai of Stavropol' province runs to over 2,000 pages (1910-1911). Russian ethnographic journals of the time featured a number of articles on the North Caucasus Turkmen (e.g., Bregel 1995, 2:1116-1122), ${ }^{32}$ including S. V. Farforovskii's “Trukhmeny (Turkmeny) Stavropol'skoi gubernii" (1911), a report entitled "Sredi stavropol'skikh turkmenov i nogaitsev i u krymskikh tatar: otchet o komandirovke v 1912 g." by the great Ukrainian Turkologist A. N. Samoilovich (1913), and two articles by A. Volodin in Sbornik materialov dlia opisaniia mestnostei $i$ plemen Kavkaza (1908a, 1908b). The latter article by Volodin contains a 1902 photograph of a North Caucasus Turkmen extended family (see fig. 4) as well as what is arguably the first instance of a North Caucasus Turkmen text appearing in print (see fig. 5). Volodin's primary source material was collected directly from the North Caucasus Turkmen among whom he lived and taught for several years, and was translated into Russian not by him but by members of that community themselves (Volodin 1908a, 1). This century and more of Russian-, Turkish- and Turkmenlanguage scholarship on the North Caucasus Turkmen community has barely been acknowledged 


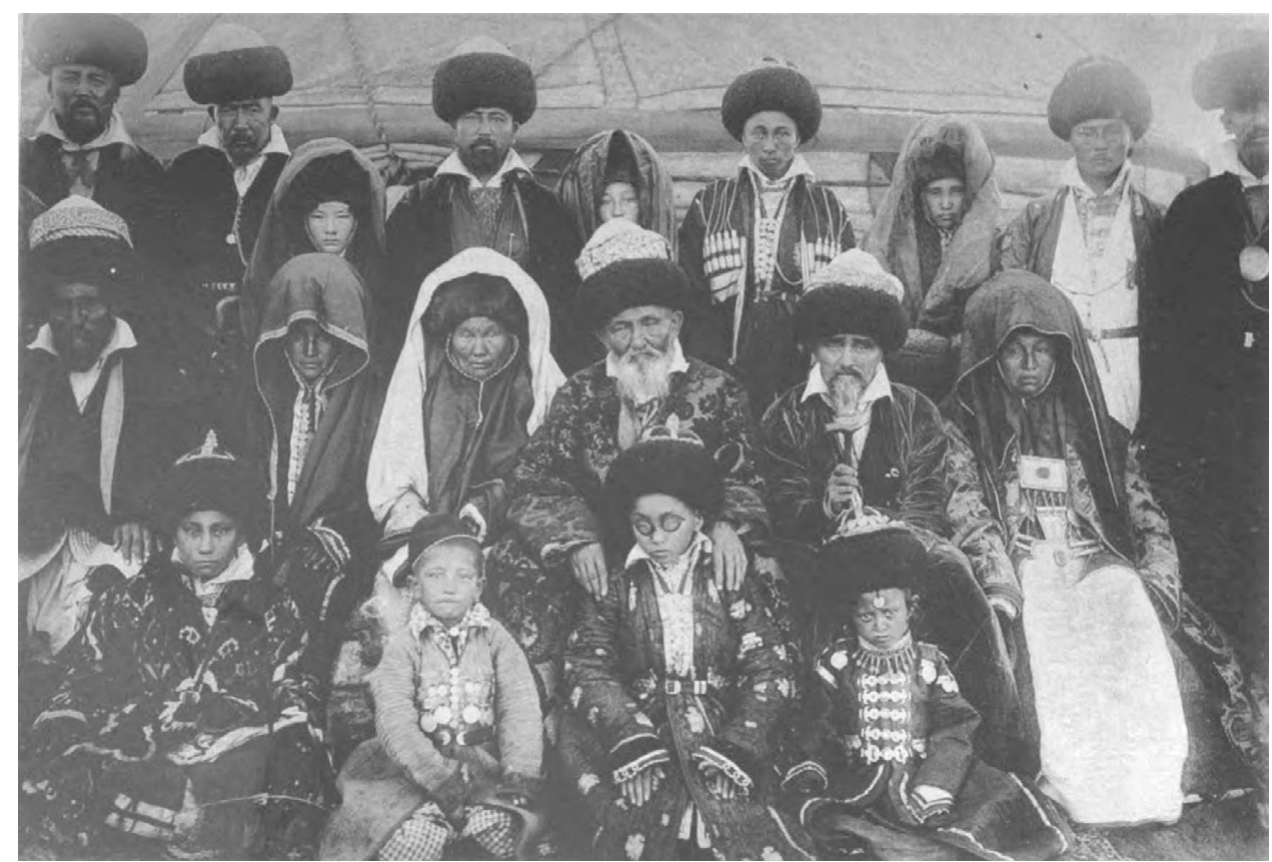

Figure 4. Abdula Adzhi and his extended family in Kucherla, Stavropol' Province, 1902. (Photograph by G. Kanevskii. A. Volodin, "Trukhmenskaia step' i trukhmeny," Sbornik materialov dlia opisaniia mestnostei i plemen Kavkaza 38 [1908], Otdiel I, second subsection, opposite p. 30.)

by Euro-Atlantic scholars, much less incorporated into their own studies of Turkmen identity, the Turkmen diaspora, and the comparative study of language, literature, linguistics, conflict, coexistence, and diasporas in general across Central Eurasia and beyond, which is the subject of the next section.

\section{The Possibilities of Particularity}

At this point in the article it would probably be wise to reiterate that the reason I am arguing so forcefully for the importance of North Caucasus Turkmen publications is not because they are particularly profound, informative, or incisive. Given our extremely limited access to them at the present time, it is impossible to say. Nor is it my role, as a librarian, to pass judgment on their worth as literary, sociological, or historical texts. I am arguing for their importance because they are representative of thousands of other numerically small groups, both diasporic and indigenous, whose experiences, traditions, language, and history, as reflected in their own vernacular-language publications, have something to tell us about the human condition. In particular, groups like the Turkmen of the North Caucasus have something to tell us about the nature of national identity, especially along the troubled and geopolitically significant periphery of Central Eurasia.

There are many small and somewhat-isolated ethnolinguistic communities around the world whose connections to larger polities, ethnicities, and identities are clear, and like the North Caucasus Turkmen, they, too, tend to be ignored in Euro-Atlantic scholarship. A few examples from Eurasia will be briefly explored by way of illustration. Firstly, the ancient Pontic Greek communities of the Black Sea region, and, after significant waves of emigration in the 20th century, of Greece itself, also have their own publication history (Akopian 2012), providing interesting perspectives on questions of Greek ethnolinguistic and national identity. These questions have been the subject of countless scholarly works in multiple Euro-Atlantic languages, but almost all of them 


\section{Изъ трухменской народной поззіи.}

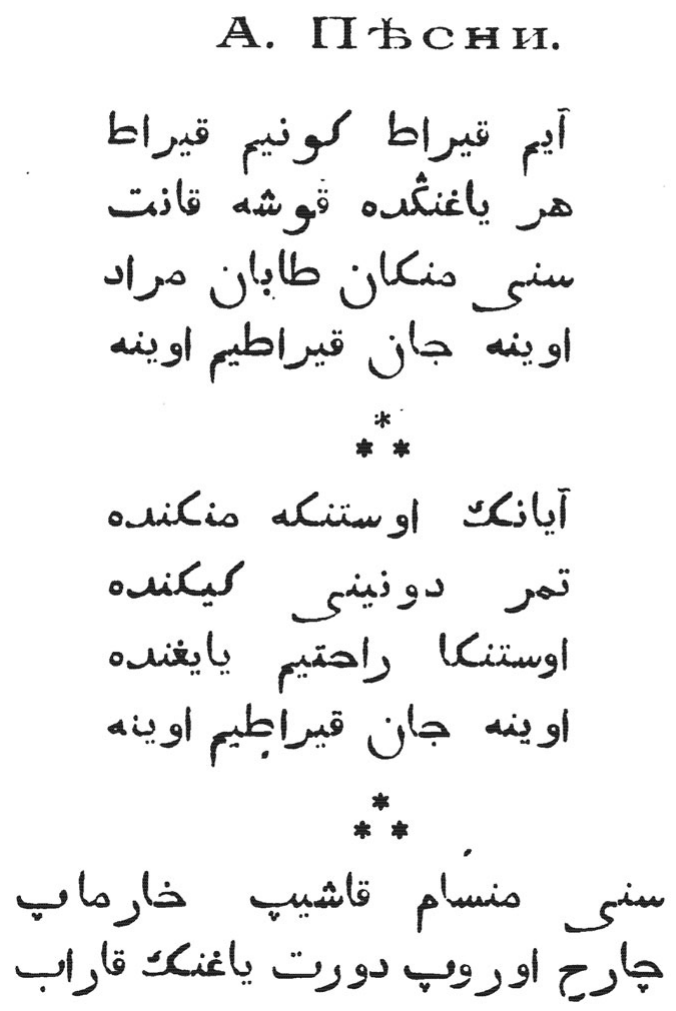

Figure 5. The beginning of a North Caucasus Turkmen song about Kirat, the legendary winged horse of the Turkic folk hero Köroğlu. (Image from A. Volodin, "Iz trukhmenskoi narodnoi poezii," Sbornik materialov dlia opisaniia mestnostei i plemen Kavkaza 38 [1908], Otdiel II, final subsection, 49.)

deal with Greek identity in the context of Greece itself, or with (non-Pontic) Greek identity in nearby areas of Anatolia under the Ottoman Empire. A search for the keyword "pontic" in Historical Abstracts, for example, yields only 35 results out of over 1.2 million in the database, and of these 35, only about 15 actually deal in some way with the Pontic Greeks (with the remainder employing the word "Pontic" to refer to the Black Sea region as a whole). A search for "pontic" and "greek(s)" in the title or abstract of the two million English-language dissertations in ProQuest's Dissertations \& Theses database yields only 20 results, many of them dealing with Greek antiquity.

Secondly, about 200 miles southeast of the North Caucasus Turkmen lies the historic homeland of the Chechens and Ingush, who constitute the North Caucasus's most populous linguistic subgroup. Chechen and Ingush dominate the Nakh branch of the Nakh-Daghestani language family and are spoken by over 1.5 million people as of 2020. Virtually no Euro-Atlantic scholars are able to read Chechen or Ingush, however, such that even the modest proliferation of Euro-Atlantic scholarly works inspired by the Russo-Chechen wars of the 1990s and their aftermath rely almost exclusively on secondary sources in Russian and other languages. This is particularly unfortunate given the availability of thousands of recent Chechen-language news articles at, for example, Marsho Radio (Radio Free Europe/Radio Liberty 2020), of catalogs of over 4,000 Chechen- and Ingush-language works held at the Russian National Library in St. Petersburg (Rossiiskaia 
Natsional'naia Biblioteka 1998a, 1997a), and other vernacular-language resources in Euro-Atlantic libraries. There is even a bibliography for the handful of works produced by Chechens and Ingush in exile in Kyrgyzstan in the early 1950s (Sergievskaia, Tantasheva, and Saatova 1962), after Stalin ordered the complete ethnic cleansing of Chechnya and Ingushetia in 1944 amid accusations of collaboration with the Nazis. The small communities of Chechens, Ingush, and other peoples of the North Caucasus who were deported in 1943-44 that still exist in Kyrgyzstan and Kazakhstan, however, like the North Caucasus Turkmen, are almost completely absent from Euro-Atlantic scholarship. Of the approximately 1,000 articles and book chapters in Index Islamicus about the Chechens, for example, only five appear to focus on the Chechen diaspora in Central Asia.

Finally, the North Caucasus Turkmen newspapers Lenin baýdagy and Güneş have analogues elsewhere that suggest how small periodical publications issued at the geographic fringes of the communities they serve can shed light on several important phenomena. The first Armenianlanguage newspaper, Azdarar, for example, was published not in Istanbul, Yerevan, or Venice but by the tiny Armenian diaspora community of Madras (modern Chennai, India) between 1794 and 1796. Azdarar has sparked a wide range of scholarly analysis in Armenian, Russian, English, and other languages (Aslanian 2014; Irazek and Ghukasyan 1986; Khachatrian 1984). Another significant newspaper published at the farthest edge of an ethnoreligious community is Sibiriya, the early20th-century newspaper of the approximately 1,500 Muslims then living in Tomsk, in central Siberia. Stéphane Dudoignon (2000) argues that despite Sibiriya's origins on the periphery of the Islamic world, it is still significant for questions of Muslim identity within the Russian Empire and is, perhaps, even more significant because the very existence of such a newspaper is unexpected. Based on these examples, Lenin baýdagy and Güneş may be able to play a similar role in illuminating aspects of Turkmen identity.

The publications of diaspora communities like the North Caucasus Turkmen raise a number of important questions. What, for example, do Soviet-era Pontic Greek publications and Chechenand Ingush-language works published in exile in Kyrgyzstan in the early 1950s tell us about Greek, Chechen, and Ingush identity, respectively? Most questions such as these have yet to be answered or even asked in Euro-Atlantic scholarship, despite the obvious truth that diaspora communities produce important cultural and historical artifacts, and not only via their publishing activity. In many ways, Euro-Atlantic scholarship on these groups, as well as the North Caucasus Turkmen, is in its infancy, and the more such groups are left out of our accounts of human history, literature, language, culture, society, politics, economics, religion, daily life, psychology, and identity formation, the more impoverished those accounts become. And meanwhile, despite (in many cases) centuries of success in maintaining a distinct identity connected to a nearby or distant homeland, the continued existence of small communities like the North Caucasus Turkmen is far from assured.

Euro-Atlantic studies of a wide range of phenomena are, therefore, impoverished and even seriously compromised by exclusion-not of one small diaspora community in the North Caucasus, but of all manner of small communities that have evaded sustained, or even desultory, scholarly attention for a wide variety of reasons. I use the term "impoverishment" deliberately to echo the work of comparative literary scholar Rebecca Gould $(2016$, 24; 2013) on the strikingly multilingual literature of the North Caucasus, which she correctly claims is ill-served by a focus only on languages that a certain critical number of Euro-Atlantic scholars can read-which, in the case of the North Caucasus, is hardly any languages at all, unless one counts the rich corpus of Arabiclanguage materials produced in pre-Soviet and Soviet Daghestan (Kemper 2010; Shikhaliev 2010; Shikhsaidov, Kemper, and Bustanov 2012). These Arabic materials, too, are an excellent illustration of the phenomenon wherein a substantial body of primary sources, which have already been interpreted and evaluated in an equally substantial body of secondary (Genko 1941; Navruzov 2011) and tertiary (Osmanova 2008) ${ }^{33}$ sources written in languages that are also relatively accessible to Euro-Atlantic scholars-Russian and Turkish, in this case-are roundly ignored in North America and Western Europe (Condill, forthcoming). Just as it is hard to imagine a justification for the exclusion of the Arabophone culture, literature, and scholarship of the North Caucasus from 
consideration alongside all of the other Arabophone traditions in existence from Morocco to Oman, it is hard to imagine a justification for excluding the North Caucasus Turkmen (and the Turkmen of Iran and Afghanistan even more so) from a comprehensive consideration of Turkmen identity. Furthermore, the fact that these perspectives have effectively been excluded from Euro-Atlantic scholarship so far makes them even more valuable, since every contention and characterization that has been made to date can now be tested against new data.

What I am advocating for is the proliferation of studies such as David Brophy's Uyghur Nation (2016), which traces the impact of Uyghurs who lived and worked in the Russian Empire/Soviet Union on the social, cultural, political, intellectual, religious, and economic life of Uyghurs in Uyghurstan (Xinjiang) itself. A significant increase in studies such as Brophy's would not only justify the acquisition of new materials from marginalized communities by Euro-Atlantic research libraries, but also be made much more feasible and successful by libraries' efforts to build those same collections. James Meyer's (2014) account of the lives and influence of the trans-imperial Turkic activists Yusuf Akçura, Ahmet Ağaoğlu, and Ismail Gasprinski also falls into the same category, along with Sean Roberts's (1998) article on the long-standing connections among Uyghurs on both sides of the Kazakh-Chinese border.

But it is Brophy that may suggest the most intriguing approaches to studying the North Caucasus Turkmen and their place as simultaneous members of the Turkmen diaspora, of the Turkmen nation, and of the multiethnic North Caucasus. Like Brophy's swirling concatenation of Uyghurs, Uzbeks, Kazakhs, Tatars, and others moving across shifting borders at the edges of empires, the diverse, complex, and highly interconnected milieu of the North Caucasus highlights the important role that can be played by members of small communities far from traditional centers of power and influence. Both Brophy's protagonists and the North Caucasus Turkmen were, and are, part of a cross-pollination of ideas, influence, finance, and forms of legitimacy between various segments of what can be seen as a single community spread across multiple polities.

Euro-Atlantic scholarship would benefit from works like Brophy's and Meyer's for many more border regions, for many more diaspora communities, and for the people, ideas, and resources that circulate between them and the homeland. Figures like Tumaýylow can provide significant insights into how diaspora communities perceive themselves, and how they are perceived, in turn, from the perspective of the homeland. As a North Caucasus Turkmen in the immediate aftermath of the Russian Revolution, Tumaýylow, unlike so many of his politically active counterparts from neighboring ethnic groups, gravitated toward Aşgabat rather than toward Stavropol', Makhachkala, or Vladikavkaz, and once he got there, he quickly rose to the highest echelons of the Soviet administration. Even though he belonged to a community that had existed in the North Caucasus for nearly three centuries, Tumaýylow obviously still considered himself a Turkmen, and he was considered to be one by the party apparatus in Aşgabat as well. Comparisons between him and the North Caucasus Turkmen who stayed at home and pursued other options-including anti-Soviet ones-would be instructive and would provide an excellent test case for contentions about Turkmen identity made by Edgar, Clement, Frank, and others. But the broader significance of figures like Tumaýylow, who moved from the margins of his imagined community to its very epicenter and, once there, became caught up in globally significant political affairs originating thousands of miles away, is that they indicate the existence of thousands of other Tumaýylows around the world-people whose lives, works, ideas, and legacies, while perhaps less dramatic than Tumaýylow's, are no less revealing in terms of the nature and consequences of national and ethnic identity and how they are conceptualized in different contexts. And far from being less valuable because they originate on the margins, stories like Tumaýylow's have the potential to validate or upend current concepts of identity.

The evidence-Turkmenets Stavropol'skii, Tumaýylow's missing magnum opus, Gyz beruw, Lenin Baýdagy, Stavropoldan salam, Güneş, and other publications and phenomena-shows that even the North Caucasus's tiny slice of the millions-strong Turkmen diaspora has much to contribute to our understanding of Turkmen identity. Surely Clement's observation, for example, 
that "literacy, language and learning contributed centrally to the development of Turkmen national identity" $(2018,173)$, should be tested against the apparent strength of Turkmen identity in the North Caucasus, far from the committees, schools, primers, and other markers of identity that flourished across the Caspian Sea in the early Soviet era. Perhaps Frank's argument that a strong, specifically Turkmen identity pre-dated both the Russian Revolution and Jadid-inspired educational reforms (Frank 2020, 306-307) would find corroboration in the North Caucasus. And surely the Turkmen of the North Caucasus and their publications could provide a means to confirm, challenge, or refine Edgar's assertion that "a Turkmen national identity emerged through a dynamic process of interaction between Bolshevik and Turkmen ideas and practices" (2004, 262). The North Caucasus Turkmen, given their physical and political distance from Aşgabat, would also serve as an excellent entry point for investigations of Isaacs and Polese's (2015) "real" versus "imagined" national identity.

The forces that caused the Turkmen of the North Caucasus to commission a Russian naval destroyer in 1905, that drew Tumaýylow to Aşgabat and to a leading role in Turkmen political affairs in the 1920s, that created a Turkmen National District in Stavropol' Krai in 1925, that caused Hajynazar Jumanýyazow to write a Turkmen-language play and get it published in Moscow in 1928, that made a Turkmen-language newspaper in Letniaia Stavka possible in the 1930s, that drew Sapar Kürenow to do research in the North Caucasus in the 1960s, that motivated Jumahaset Ylýasow to publish his book of poems in Aşgabat in 1994, and that once again facilitated the publication of a Turkmen-language newspaper in the North Caucasus in the 1990s and 2000s all speak to a powerful sense of Turkmen identity despite centuries of separation from Turkmenistan proper-a sense of identity that may not be fully explained or explainable by the available Euro-Atlantic scholarship on Turkmen identity.

A complete analysis of the forms that Turkmen identity has taken in the unique conditions of the North Caucasus will have to wait for access to Tumaýylow's magnum opus, Gyz beruw and other early Soviet plays, and Lenin baýdagy and Güneş, but this much seems clear: Turkmen identity, the role of diaspora populations, and the borders and contours of identity in general are more complicated than Euro-Atlantic scholarship and Euro-Atlantic library collections have been able to express so far. Taking a microscope to one small portion of the Turkmen diaspora can serve as a step in the right direction.

Yet, once again, it must be conceded that the entire content of the vernacular-language North Caucasus Turkmen sources whose existence is painstakingly unearthed or tantalizingly hinted at in this article may not be enough to launch a monograph or a dissertation on the North Caucasus Turkmen. Perhaps they only deserve a footnote, or a shrug. But even if that is true, it is still important to make arguments from the margins in this way, because they throw everything else into sharp relief. If the North Caucasus Turkmen have not published enough, or are not numerous enough, or are not important or interesting enough to justify or warrant a serious scholarly treatment in the Euro-Atlantic world, then what about the neighboring Nogais, whose ancestors established a significant late-medieval polity (the Nogai Horde), who have over 1,500 works published in their language held at the Russian National Library in St. Petersburg, and who today are 100,000 strong and live all over the North Caucasus? Are their vernacular-language works worthy of study by Euro-Atlantic scholars, or not? If not the Nogai, what about the Kumyks, from whose ranks many of Daghestan's most prominent leaders, scholars, educators, and authors have been drawn, who have over 3,000 vernacular-language published works dating back to 1883 held at the Russian National Library, and who currently number over 500,000? What about the Lezgis of southern Dagestan and northern Azerbaijan, with over 2,500 works at the Russian National Library and a population as high as one million (Rossiiskaia Natsional'naia Biblioteka 1997c, 1998b, 1997b)? At what point does it become imperative for Euro-Atlantic scholars to acquire the necessary language skills to engage with a corpus of material of this size? How many articles, books, and dissertations based on vernacular-language materials does a given ethnic group "deserve"? Should the answer depend on the relative difficulty (or ease) of learning their language 
for English speakers? Should it depend on whether Euro-Atlantic libraries already have strong collections of materials in that language?

Perhaps the exclusion, thus far, of the North Caucasus Turkmen or of any single one of the thousands of similarly marginalized groups around the world from the Euro-Atlantic scholarly record is not too tragic in terms of the advancement of human knowledge, which, historically, has been gradual, fitful, and liable to experience setbacks and reversals in any case. But surely a highly developed, centuries-old, massively multiethnic society of approximately 7 million indigenous people existing in a geopolitically significant and conflict-prone region the size of the US state of South Dakota (i.e., the North Caucasus as of 2020) is worthy of study as a system or a totality, and the study of that totality is impoverished by the exclusion or neglect of any one group within it. When taken together, the extraordinary diversity of the peoples of the North Caucasus presents a nearly unique situation in human history, begging the question of why this region is so under-studied in the Euro-Atlantic world. ${ }^{34}$ Yes, the languages are difficult; yes, the published and unpublished materials are hard to access and acquire; yes, the alphabets have changed many times over the last 150 years; yes, it has been dangerous and sometimes impossible to do fieldwork there for many decades. But the secondary sources are plentiful; they are largely written in languages (Russian and Turkish) that Euro-Atlantic scholars have every opportunity to learn; and the difficulties associated with transliteration, general lack of awareness, and poor Euro-Atlantic library collections are ultimately unnecessary, and can be overcome with a modicum of collective effort.

In other words, the scholarly significance of the North Caucasus as a region is greater than the sum of its parts and cuts across many disciplines. It provides fertile ground for comparative studies of many kinds and provides an opportunity for Euro-Atlantic libraries to play a major role in cultural and linguistic preservation efforts. The Turkmen of the North Caucasus present an ideal test case for a wide variety of research propositions. Surely the theories advanced to explain nationalism and national identity in Indonesia, Egypt, Argentina, Uzbekistan and elsewhere can productively and provocatively be tested against the national sentiment, or lack thereof, among groups like the North Caucasus Turkmen. They can provide insight into larger questions, such as why the Turkmen state has been so ambivalent about its relations with Turkmen populations directly across its borders, and why there has been essentially no self-determination or panTurkmenist movement among the Turkmen of Iran and Afghanistan, even as the latter country has existed in a state of profound fragmentation for decades. Also, since the Turkmen (or "Turkmen") of Uzbekistan, Kazakhstan, Tajikistan, Iran, Afghanistan, China, Iraq, Turkey, Syria, and Russia live under a wide variety of authoritarian regimes of differing intensities, goals, and experiences of recent or not-so-recent violent conflict, perhaps they can tell us something about adaptation, the persistence and mutability of identity, and authoritarianism itself.

In addition, what can the North Caucasus Turkmen, whose history is so intimately intertwined with their neighbors the Kalmyks, tell us about the aftermath of ethnic cleansing, given that the Kalmyks were deported to Siberia as supposed Nazi collaborators in 1944 while the North Caucasus Turkmen were not? What about the other Turkic peoples of the North Caucasus that were deported, the Karachais and Balkars who lived 150 miles away near the base of Mt. Elbrus? What about the experience of the North Caucasus Turkmen under Nazi occupation in late 1942? What about the position of the North Caucasus Turkmen as a link between the sedentary populations to their south and the nomadic world to their north, which stretches around the northern edge of the Caspian Sea and all the way to Iran, Mongolia, and beyond? What about the fact that the North Caucasus Turkmen, with their various linkages to other Turkmen in Turkmenistan and elsewhere, are simultaneously enmeshed in the remarkable ethnolinguistic diversity of the North Caucasus itself, ${ }^{35}$ with its history of violence, resistance, insurgency, and conflict, but also of coexistence, solidarity, multilingualism, pluralism, and the preservation of the languages, cultures and traditions of tiny ethnic groups over many millennia? While many of the ethnolinguistic groups of the North Caucasus have large diasporas in the Middle East and elsewhere, what about the fact that the 
Turkmen are almost unique in that their coethnics in Turkmenistan proper are also the titular ethnicity of a sovereign state? ${ }^{36}$

Despite all these possible avenues for research, the combined neglect of scholars and librarians has effectively erased the Turkmen of the North Caucasus from existence in the Euro-Atlantic world. If we do not write them and the thousands of other groups like them back in, our understanding of the human experience will be diminished, perhaps forever. ${ }^{37}$ The great library collections of the Euro-Atlantic world have been and continue to be shaped by thousands of small collection-development decisions. While these decisions may seem inconsequential at the time, they can end up influencing the course of Euro-Atlantic scholarship in profound ways. When we librarians fail to do due diligence on the areas that we cover, when we fail to continually reimagine our collections, when we fail to challenge ourselves, our staff, and, most importantly, our administrators, when we fail to pursue projects or goals that are difficult to achieve, then scholarship as a whole suffers, and libraries' role as collectors and protectors of the common cultural heritage of humankind is not fulfilled. We should not accept statements like Wixman's at face value. We should not rely on vendors whose motivations are different than our own to seal the fate of groups like the Turkmen of the North Caucasus, Pontic Greeks, and Chechens and Ingush in Central Asia forevermore. We should not allow our collections to become impoverished because "no one on our campus at the moment reads this language or alphabet" or because "no one is currently teaching a course on this country/people/region."

With that kind of short-sighted thinking, our understanding of the world-through, in this case, our understanding of Turkmen identity-will ultimately become impoverished as well.

To evaluate blanket statements about the (non)existence of potential library materials, to uncover previously unknown sources, to expand our picture of human knowledge and human endeavor and the comprehensiveness of the permanent record thereof in the world's libraries: these things are arguably the essence of a librarian's job. If there are North Caucasus Turkmen newspapers, plays, and poetry out there that even Ýazberdiýew failed to identify as such, what else are Euro-Atlantic libraries missing, and how will the scholarship and worldview of future generations be shaped or impoverished as a result?

Acknowledgments. I would like to take this opportunity to thank the Interlibrary Loan Department at the Library of the University of Illinois at Urbana-Champaign, and in particular Kathy Danner and Alissa Marcum, for supplying hundreds of obscure sources that I needed for the present article and for the broader research that underlies it. I would also like to thank my family, and especially my wife Emily, for their love and support, and for giving me the many, many evening and weekend hours I needed in order to complete this project.

Disclosures. Author has nothing to disclose.

Financial Support. This work was supported in part by the Research and Publication Committee of the Library of the University of Illinois at Urbana-Champaign, and by the Library's Ralph T. Fisher Professorship Fund.

\section{Notes}

1 At least four different alphabets have been used for Turkmen in the last hundred years, which makes it difficult to select a so-called correct spelling for various surnames and other terms. In this article, when a specific Turkmen source is cited, the author's name is spelled as it appears in that source (and is also, when necessary, transliterated into Latin script according to the Library of Congress transliteration system). Otherwise the current (post-1999) Latin script for Turkmen is used. Hence I use Ýazberdiýew when referring to him as a bibliographer, but Iazberdyev (= Язбердыев) when citing his Cyrillic-script 1981 bibliography. During the Soviet era many Turkmen had both Turkmen and Russian versions of their names as well, which is why some of Ýazberdiýew's other works (Iazberdiev [2001], Iazberdiev [1993]) are cited in the bibliography as being authored by Iazberdiev (Язбердиев). The 2005 Turkish-language edition of Iazberdyev 
(1981) is filed under "Yazberdiyev," as his name appeared in that particular publication. In my view this multiplicity of forms is unavoidable, because without the version of the name actually used in a particular work, it can be very difficult to find a copy in a Euro-Atlantic library catalog. In other words, this system is intended to both provide the currently accepted Turkmen spelling of Turkmen names and terms and to facilitate searching in Euro-Atlantic library catalogs.

2 This seems a bit counterintuitive, but it is explained by the New York Public Library's remarkable collection of early Soviet Arabic- and Latin-script publications from Central Asia and the Caucasus, as documented in Allworth (1971). NYPL's Turkmen-language items from this era are listed on pages 184-191.

3 These figures are taken from a separate and much larger study of US collections of Turkiclanguage materials in general, which I will be publishing results from in 2021 . While that study focuses only on US library holdings, it is clear from the study's extensive sampling and searching that library holdings of Turkmen-language materials in Canada and Western Europe are also quite poor.

4 Although reliable figures are virtually impossible to come by, after nearly 30 years of seemingly capricious authoritarian rule, the actual population of Turkmenistan in 2020 may be much lower than 5 million (and the diaspora, correspondingly, that much bigger, with new waves of emigrants settling in Russia, Kazakhstan, and Turkey). See Najibullah (2019) and Eurasianet (2020). If even partially true, then at the present time the Turkmen diaspora is probably more significant for Turkmen identity than at any time since the demarcation of Turkmenistan's current borders in 1924.

5 For Durdyev's “enthusiastic and skillful defence" of his "perverse view of Turkmen nationalism," see Christian (1995). See also Gundogdyev (2012), in which arguments are advanced for the Turkmen origins of a wide variety of peoples, and Kirchanov (2010) for a critique of Gundogdyev's earlier contentions.

6 See entries \#693 to \#719 in Iazberdyev (1981, 220-224). All 27 of these works were published between 1969 and 1976. An additional indication of Ýazberdiýew's own interest in the Turkmen diaspora can be gleaned from the fact that several of his works have been translated into Turkish and Persian and published in Turkey and Iran; see Ahunjanow, Hudaýkulowa, and Aýdogdyýew (2009, 101, 106, 163-164).

7 In 2016, for example, the Russian and Turkmen Academies of Sciences produced a 634-page tome (Dubova 2016) on all aspects of Turkmen history and culture as part of the Russian Academy of Sciences' series Narody i Kul'tury; the chapter “Turkmenskaia Diaspora” (469-504) includes sections on the North Caucasus Turkmen (Brusina 2016b), the Astrakhan Turkmen (Amanlyev 2016), and the Salars (Rezvan 2016), but it includes nothing on the Turkmen of the Middle East or Afghanistan. In Turkey, supposed Turkmen supposedly assimilating to a Kurdish identity are the subject of some anxiety; see Özdemir (2014). See also UNPO (2015).

8 For more on the Astrakhan Turkmen, who have their own publication history, see Amanlyev (2016) and Kadyrov (2001-2015, 1:113, 2:175-176, 302-303) (i.e., the entry for author, educator, publisher, and pumpkin farmer Abdyrahman Nyýazy, or Abdurakhman Niiazi [1857-1929]). Incidentally, Kadyrov (2001-2015, 1:285) also contains an entry for a destroyer in the Russian Navy's Baltic fleet that was commissioned in 1905 and paid for by the North Caucasus Turkmen community. At various points in its existence, this ship was christened the Turkmenets (19051908), the Turkmenets Stavropol'skii (1908-1920), the Mirza Kuchuk (1920-1922), the Al'fater (1922-1945), and the Sovetskii Dagestan (1945-). The fact that the North Caucasus Turkmen had the means and the inclination to demonstrate their support of the Tsarist government during the Russo-Japanese War in this way is further evidence that this community has never been as marginal and insignificant as Euro-Atlantic scholarship now makes it appear to be.

9 This technique is described in Husic (2017). As Husic (117) discusses, due to incorrect coding as well as different methods of handling multilingual works, these 6,522 records do not necessarily include every single Turkmen-language work in the WorldCat database. 
10 For example, there are at least six records for the main newspaper of Soviet Turkmenistan, the aptly named Sovet Turkmenistany (Ashgabat, 1936-1991), two records for Gylychdurdyev (1967), three records for Türkmenistanyň Prezidentiniň Arhiw gaznasy (2007), and five records for the weekly literary newspaper of the Turkmenistan Writers' Union, Edebiiat ve sungat (Ashgabat, 1958- ).

11 This was Aşgabat's official name from 1919 to 1927.

12 This spelling is based on the short-lived mid-1990s Latin alphabet for Turkmen, in which, among other characters based on currency symbols, the capital letter \$̧ was represented by a dollar sign (\$) and the lowercase ş was represented by the cent sign $(\phi)$.

13 See, for example, Mehmet Aça, Tıva halk masalları (Konya: Kömen Yayınları, 2007), which should clearly be coded as "tyv" (Tuvan) rather than "tuk" (Turkmen); 'Abd al-Rahman Basha, Bonuvoni sahoba, namunahoi shoista (Dushanbe, 2010), which is a Tajik translation of some of Basha's biographies of the female associates of the prophet Muhammad, originally written in Arabic; the Russian/Altai literary journal El-Altai, published in Gorno-Altaisk near the Mongolian border; a Russian-language medical treatise on diabetic angiopathy (or, as it appears in WorldCat: Fedorova, P. I. Angiopatii pri sacharnom diabete. Taskent: Izd. Medicina, 1974); a 19th-century Welsh poetry book ("Pymtheg o gerddi Cymru, hen a diweddar, Bala: H. Evans, 1800s"); famous Irish war correspondent Edmund O'Donovan's 1882 account of his time in Mary/Merv (Edmond O'Donovan, The Merv oasis: travels and adventures east of the Caspian during the years 1879-80-81, including five months' residence among the Tekkes of Merv. London: Smith, Elder \& Co., 1882); Karl Heinz Rechinger's Flora Iranica (Craz [sic]: Akad. Dr.-u. Verlaganst., 1963) and many others.

14 See Tulu 2005; Geldiýew and Türkmen 1995; etc. There are also a handful of what seem to be state-sponsored public-relations efforts originating in Aşgabat (Aidogdyev 1999; Öner and Nepesowa 2005; etc.); a handful of translations of religious texts into Turkmen, such as Suruç 1999; and a handful of other works published by Turkmen authors in Turkey, such as Nurmemmet 1996.

15 The Mangyshlak Peninsula has been part of Kazakhstan since 1924. The former Turkmen population of Mangyshlak was largely dispersed to other regions (mostly to modern-day Turkmenistan, but also to Astrakhan and Stavropol') by Kalmyk and Kazakh raids in the 17 th and 18 th centuries.

16 The North Caucasus Turkmen are also given a single paragraph in Akiner $(1983,265)$, where they are referred to as the Truchmen, and a few lines in Bennigsen and Wimbush (1986, 94-95, 148).

17 The Russian source cited is Brusina (2008). A similar passage appears in an earlier work by Peyrouse $(2007,69-70)$. Staudinger $(2012,41-42)$ also includes a brief overview of the Turkmen diaspora, which devotes two sentences to the North Caucasus Turkmen but cites only Akiner $(1983,265)$ and Bennigsen \& Wimbush (1986, 94-95).

18 Edgar (2004) devotes three pages to the Turkmen Bolshevik Mahmyt Tumaýylow (Mahmut Tumailov) and the so-called Tumailov Affair of 1927, noting that Tumaýylow was a "member of the tiny community of Stavropol Turkmen in the North Caucasus" and that he "frequently noted with pride that when he joined the Communist Party at the age of seventeen, he was the first Turkmen from the North Caucasus to do so" (115). Edgar does do justice to Tumaýylow's rather spectacular impact on the political scene in Turkmenistan in the late 1920s, but the North Caucasus Turkmen themselves do not emerge as an object of study.

19 Staudinger $(2012,41)$ estimates the percentage of the Turkmen population of Afghanistan that is descended from Soviet refugees of the 1920 s and 1930 s at $60-70 \%$. A similar figure is provided in Kadyrov (2001-2015, 1:287).

20 Sunderland also alludes to the North Caucasus Turkmen as (in the words of the Svod zakonov Rossiiskoi Imperii) "nomadic aliens" $(2004,146)$. 
21 Although it would be a stretch to characterize it as a reference to (what later became) the Turkmen diaspora, Frank does make a passing reference to the idea that Turkmen identity-or at least an identification with legends and genealogies that were also important to the Turkmen of modern-day Turkmenistan-existed in the Volga-Ural region and elsewhere prior to 1917 $(2020,307 \mathrm{n} 63,309)$.

22 To his credit, Reiss $(1983,444)$ also cites a Russian-language source on the North Caucasus Turkmen in his closing bibliographic essay, namely, Pan'kov (1960).

23 Shamil was the leader of what was arguably the most successful war of resistance in Russian history, keeping the imperial army at bay in the North Caucasus for over 25 years between 1834 and 1859. For more information on Princeton's holdings, see Kemper, Shikhsaidov, and Tagirova (2002) and Tahirova (2002). Retrieving all of Shamil's manuscripts with a single search in Princeton's Digital Library seems to be impossible, but several of them can be accessed via a keyword search for "shamil" at the Princeton University Digital Library (http://pudl. princeton.edu/search.php).

24 As of February 2020, a beta version of a database providing access to these materials is available to affiliates of the University of Illinois at Urbana-Champaign (http://iisdev.library.illinois.edu/ Uzbek).

25 Since the old Soviet-era Cyrillic script for Turkmen is still used among the North Caucasus Turkmen, Güneş would become Günesh when rendered into Latin script via the Library of Congress transliteration system.

26 Weliýew (Veliev), under the auspices of the Turkmen Academy of Sciences' Magtymguly Institute of Language and Literature, was also the compiler of an earlier book of North Caucasus Turkmen folk poetry (Veliev 1980).

27 Other translations of these words (özbashdak from the original Turkmen-language edition [Kurenov 1962] and müstakil from the 1995 Turkish edition) include "independently," "without authorization," and "without permission," which may help to explain why bibliographic traces of it are so hard to find.

28 It is not my intention to criticize my colleagues at other libraries either. Certainly there are many deficiencies in my own institution's catalog that should be fixed before I start criticizing the cataloging practices of others. And the New York Public Library's collection of early Soviet-era materials in Arabic script, in addition to being one of the most remarkable and most irreplaceable collections in the country, is exceedingly difficult to catalog, as the numerous obvious errors in Allworth's bibliography can attest. Furthermore, as of 2020, there is still no standard system of transliterating Arabic-script Turkmen into Latin script for inclusion in Euro-Atlantic library catalogs in any case. Of the formerly SovietCentral Asian languages written in Arabic script prior to 1929, only Kazakh (Library of Congress 2012) and Uzbek (Library of Congress 2017) have thus far received a transliteration table from the Library of Congress.

29 All 21 volumes of Türkler are freely available online via the Internet Archive as of July 2019 at https://archive.org/stream/TurklerAnsiklopedisi/. Murtaza Jumanyiazov (as Kürenov spelled his name in 1962) is also discussed in Kürenov $(1995,75-79,1962,91-95)$.

30 The four are Yale University, Columbia University, the University of Chicago, and the University of Illinois. The title of the microfiche set is "Card catalog of the Department of the Literature of the Nationalities of the former Soviet Union from the National Library of Russia, St. Petersburg on microfiche," published by Norman Ross. Individual parts of the set are entitled Katalog literatury na turkmenskom yazyke, Katalog literatury na nogaiskom yazyke, etc.

31 For more detail on Tumaýylow, see Edgar (2004, 115-118), Soegov (2014), and Kadyrov (20012015, 1:281-282).

32 To return briefly to the dire pronouncements about the state of Euro-Atlantic research on the Turkmen from the beginning of this article, as of February 2020, it is virtually impossible to find any reference to any of these standard works on the North Caucasus Turkmen in JSTOR, Scopus, Hathi Trust, or Google Books, with the exception of my own articles in Slavic \& East European 
Information Resources on the Turkic peoples of the North Caucasus (Condill 2017, 2018 and 2019).

33 Pre-1930 publications in the local languages of the North Caucasus, incidentally, have been ably recorded in the published catalogs of Amirkhan Isaev $(1989,2012)$.

34 For more on the state of North Caucasus Studies in general in the Euro-Atlantic world, see Condill $(2017,2018,2019)$.

35 Any doubt about whether the Turkmen should be included among the ethnicities of the North Caucasus, due, for example, to their physical location on the pasturelands at the northern fringes of the region, should be dispelled by the fact that they are very much considered a part of the region in Shcheglov (1910-1911) and that the short-lived and rather nominal Mountain Republic of 1918-1920, which attempted to unite all of the peoples of the North Caucasus in an independent anti-Soviet state, was keen to include the Turkmen (Vachagaev 2018, 69-70); certain Turkmen villages were actually administratively part of Daghestan as part of the Achikulakskii raion from 1922 to 1938, and one of them (present-day Makhach) was named after the Kumyk head of the first Soviet government of Daghestan. Also, the ulema of the North Caucasus Turkmen villages are typically educated in Daghestan (Brusina 2008, 33); and in the 19th century, the North Caucasus Turkmen played an important role in the transportation of goods from European Russia to Tiflis via camel caravan (Kurbanov 1995, 104-105).

36 Of the ethnolinguistic groups present in the North Caucasus at the time of the Russian conquest, only the Turkmen and the Azerbaijanis of southern Daghestan currently have a sovereign state in which their co-ethnics are the titular nationality. The Turkmen, uniquely, are separated from the borders of their sovereign state by hundreds of miles, while the Azerbaijani population is contiguous across the Russian-Azerbaijani border.

37 The oft-quoted statistic is that $50 \%$ to $90 \%$ of the world's 6,000 extant languages will disappear by the year 2100 (Austin and Sallabank 2011, 2).

\section{References}

Aidogdyev, Orazgeldi. 1999. Turkmenbashy turkmeni dunya tanadiar $=$ Turkmenbashy and Turkmenistan $=$ Turkmenbashi $i$ Turkmenistan. Ankara: Matsa Basimevi.

Ahunjanow, E. A., M. Hudaýkulowa, and M. A. Aýdogdyýew, comps. 2009. Almaz Berdiýewiç Ýazberdiýew. Türkmen alymlary 37. Aşgabat: Merkezi ylmy kitaphana (Türkmenistanyñ Ylymlar akademiýasy).

Akiner, Shirin. 1983. Islamic Peoples of the Soviet Union. London: Kegan Paul International.

Akopian, Viktor Zavenovich. 2006. Severnyi Kavkaz prirodno-geograficheskii, etnodemograficheskii, i istoricheskii: ocherki [The North Caucasus - environmental-geographic, ethnodemographic, and historical aspects: essays]. Piatigorsk: PGLU.

Akopian, V. Z. 2009. Natsional'no-gosudarstvennoe i administrative-territorial'noe stroitel'stvo na Severnom Kavkaze v 20-30 gg. XX v.: uchebnoe posobie [National and administrative-territorial development in the North Caucasus in the 1920s-1930s: A textbook]. Piatigorsk: PGLU.

Akopian, V. Z. 2012. "Periodicheskaia pechat' i izdatel'skaia deiatel'nost' grekov Severnogo Kavkaza v sovetskii period" [The periodical press and publishing activity of the Greeks of the North Caucasus during the Soviet era]." Istoricheskaia $i$ sotsial'no-obrazovatel'naia mysl' 16 (6): 13-16.

Alikberov, Alikber Kalabekovich, and Vladimir Olegovich Bobrovnikov, eds. 2010. Dagestan i musul'manskii Vostok: Sbornik statei $=$ Daghestan and the Muslim East: Studies on History and Sources in Honor of Amri Shikhsaidov. Moskva: Mardzhani.

Allworth, Edward. 1971. Nationalities of the Soviet East: Publications and Writing Systems: A Bibliographical Directory and transliteration tables for Iranian- and Turkic-Language Publications, 1818-1945, Located in U.S. Libraries. New York: Columbia University Press.

Amanlyev, N. 2016. “Turkmeny Astrakhanskoi oblasti Rossii” [The Turkmen of Russia's Astrakhan province]. In Turkmeny, edited by N. A. Dubova, 492-504. Moskva: Nauka.

Ashirova, Aygul. 2009. Stalinismus und Stalin-Kult in Zentralasien: Turkmenistan, 1924-1953. Soviet \& Post-Soviet Politics \& Society 89. Stuttgart: ibidem-Verlag.

Aslanian, Sebouh D. 2014. "Port Cities and Printers: Reflections on Early Modern Global Armenian Print Culture." Book History 17: 51-93.

Ataev, Kh., ed. 1993. Turkmeny zarubezhnogo Vostoka : ocherki o turkmenakh Irana, Afganistana, Iraka, Sirii, Turtsii i Kitaia [The Turkmen of the Orient: Essays on the Turkmen of Iran, Afghanistan, Iraq, Syria, Turkey and China]. Ashgabat: Turkmenistan. 
Austin, Peter K. and Julia Sallabank, eds. 2011. The Cambridge Handbook of Endangered Languages. Cambridge: Cambridge University Press.

Avksent'ev, A. 1996. "Put' nashikh predkov" [The path of our ancestors]. Neitral'nyi Turkmenistan, September 26, 1996.

Baldauf, Ingeborg. 1993. Schriftreform und Schriftwechsel bei den muslimischen Russland- und Sowjettürken (1850-1937): ein Symptom ideengeschichtlicher und kulturpolitischer Entwicklungen. Biblioteca Orientalis Hungarica 40. Budapest: Akadémiai Kiadó.

Bennigsen, Alexandre, and S. Enders Wimbush. 1986. The Muslims of the Soviet Empire: A Guide. Bloomington: Indiana University Press.

Bregel, Yuri. 1981. "Nomadic and Sedentary Elements among the Turkmens." Proceedings of the $23^{\text {rd }}$ meeting of the Permanent International Altaistic Conference, Vienna, 27. July - 1. August 1980. Central Asiatic journal 25 (1/2): 5-37.

Bregel, Yuri. 1995. Bibliography of Islamic Central Asia. Uralic \& Altaic Series 160. 3 vols. Bloomington: Research Institute for Inner Asian Studies (Indiana University).

Brophy, David. 2016. Uyghur Nation: Reform and Revolution on the Russia-China Frontier. Cambridge, MA: Harvard University Press.

Broxup, Marie Bennigsen, ed. 1992. The North Caucasus Barrier: The Russian Advance towards the Muslim World. London: Hurst \& Co.

Brusina, Ol'ga Il'inichna. 2008. Stavropol'skie turkmeny: etnokul'turnoe razvitie, sotsial'nye obychai, protsessy adaptatsii $i$ integratsii [The Stavropol' Turkmen: Ethnocultural development, social practices, and processes of adaptation and integration]. Issledovaniia po prikladnoi i neotlozhnoi etnologii 202. Moskva: IEA RAN.

Brusina, Ol'ga Il'inichna, ed. 2016a. Turkmeny Iuga Rossii: istoricheskii kontekst $i$ sotsiokul'turnye transformatsii [The Turkmen of southern Russia: Historical context and socio-cultural transformations]. Moskva: IEA RAN.

Brusina, Ol'ga Il'inichna. 2016b. "Stavropol'skie turkmeny" [The Stavropol' Turkmen]. In Turkmeny, edited by N. A. Dubova, 469-492. Moskva: Nauka.

Christian, David. 1995. "Murat Durdyiev and Turkmen Nationalism." In Nationalism and Postcommunism: A Collection of Essays, edited by Aleksandar Pavković, Halyna Koscharsky, and Adam Czarnota, 57-81. Aldershot: Dartmouth.

Clement, Victoria. 2018. Learning to Become Turkmen: Literacy, Language and Power, 1914-2014. Pittsburgh: University of Pittsburgh Press.

Condill, Kit. 2017. “The Idea of the Comprehensive Research Collection, the Perils of 'Linguistic Impoverishment,' and Print Publications in the Turkic Languages of the North Caucasus, 1806-2017: Part I." Slavic \& East European Information Resources 18 (3/4): 128-151.

Condill, Kit. 2018. “The Idea of the Comprehensive Research Collection, the Perils of 'Linguistic Impoverishment,' and Print Publications in the Turkic Languages of the North Caucasus, 1806-2017: Part II." Slavic \& East European Information Resources 19 (1/2): 3-27.

Condill, Kit. 2019. “The Idea of the Comprehensive Research Collection, the Perils of 'Linguistic Impoverishment,' and Print Publications in the Turkic Languages of the North Caucasus, 1806-2017: Part III." Slavic \& East European Information Resources 20 (3/4): 130-161.

Condill, Kit. Forthcoming. "Reconstructing 'The Ladder of Languages' in 21st-Century Research Libraries: The Elision of the North Caucasus in Western Scholarship and Collection Development." In The Collector and the Collected: Decolonizing Area Studies Librarianship, edited by Anna Arays, Megan Browndorf, and Erin Pappas. Sacramento: Library Juice Press.

Companjen, Françoise, Laszlo Maracz, and Lia Versteegh, eds. 2010. Exploring the Caucasus in the 21st Century: Essays on Culture, History and Politics in a Dynamic Context. Amsterdam: Pallas.

Dash, Barbara L. 2008. “A Visionary Acquisition: The Yudin Collection at the Library of Congress." Slavic \& East European Information Resources 9 (2): 92-114.

Demir, Sema Aslan. 2015. "Stavropol ve Astrahan Türkmenlerinin Dil ve Kültürleri Üzerine Notlar” [Notes on the language and culture of the Stavropol' and Astrakhan Turkmen]. Yeni Türkiye: "Kafkaslar" Özel sayıs 10:449-458.

Denison, Michael. 2009. "The Art of the Impossible: Political Symbolism and the Creation of National Identity and Collective Memory in Post-Soviet Turkmenistan.” Europe-Asia Studies 61 (7): 1167-1187.

Dubova, Nadezhda Anatol'evna, ed. 2016. Turkmeny [The Turkmen]. Moskva: Nauka.

Dudoignon, Stéphane. 2000. "Un Islam périphérique? Quelques réflexions sur la presse musulmane de Sibérie à la veille de la Première Guerre mondiale." Cahiers du Monde russe 41 (2/3): 297-339.

Durdyev, Marat. 1992. Turkmeny Kitaia (Salary) [The Turkmen of China (the Salars)]. Ashgabat: Turkmenskaia Akhaltekinskaia Assotsiatsiia.

Durdyev, Marat, and Shokhrat Kadyrov. 1991a. Duniadaki Turkmenler: tarykhy-demografik syn [The Turkmen in the world: a historical-demographic overview]. Ashgabat: Kharp.

Durdyev, Marat, and Shokhrat Kadyrov. 1991b. Turkmeny mira: istoriko-demograficheskii obzor [The Turkmen of the world: a historical-demographic overview]. Ashgabat: Kharp.

Duymaz, Ali. 2002. "Kuzey Kafkasya Türkmenleri” [The Turkmen of the North Caucasus]. In Türkler, edited by Hasan Celâl Güzel, Kemal Çiçek, and Salim Koca, 920-934. Vol. 20. İstanbul: Yeni Türkiye Yayınları.

Duymaz, Ali. 2015. "Kuzey Kafkasya (Stavropol) Türkmenleri” [The North Caucasus (Stavropol') Turkmen]. Yeni Türkiye: "Kafkaslar" Özel sayısı 10:436-448. 
Edgar, Adrienne Lynn. 2004. Tribal Nation: The Making of Soviet Turkmenistan. Princeton, NJ: Princeton University Press. Episkoposov, G. L., ed. 1970-1984. Gazety SSSR, 1917-1960: Bibliograficheskii spravochnik [The newspapers of the USSR, 19171960: A bibliographic handbook]. 5 vols. Moskva: Kniga.

Eurasianet. 2020. “Turkmenistan: Security Chiefs Feeling Insecure.” Akhal-Teke: A Turkmenistan Bulletin, January $28,2020$. https://eurasianet.org/turkmenistan-security-chiefs-feeling-insecure. (Accessed November 11, 2020.)

Farforovskii, Sergei Vasil'evich. 1911. “Trukhmeny (Turkmeny) Stavropol'skoi gubernii [The Trukhmen (Turkmen) of Stavropol' Province]." Izviestiia Obshchestva arkheologii, istorii i etnografii 27 (3): 181-220.

Fénot, Anne, and Cécile Gintrac. 2005. Achgabat, une capitale ostentatoire: autocratie et urbanisme au Turkménistan. Paris: L'Harmattan.

Forsyth, James. 2013. The Caucasus: A History. New York: Cambridge University Press.

Foxall, Andrew. 2015. Ethnic Relations in Post-Soviet Russia: Russians and Non-Russians in the North Caucasus. London: Routledge.

Frank, Allen J. 2020. “Turkmen Literacy and Turkmen Identity before the Soviets: The Ravnaq al-Isläm in Its Literary and Social Context." Journal of the Economic and Social History of the Orient 63:286-315.

Geldiýew, Gurbandurdy, and Fikret Türkmen. 1995. Türkmen şiiri antolojisi [An anthology of Turkmen poetry]. Ankara: Türksoy Yayınları.

Genko, Anatolii Nestorovich. 1941. “Arabskii iazyk i kavkazovedenie: o znachenii arabskikh materialov dlia izucheniia istorii Kavkaza” [The Arabic language and Caucasus Studies: On the significance of Arabic materials for the study of the history of the Caucasus]. Trudy vtoroi sessii Assotsiatsii arabistov, 19-23 oktiabria $1937 \mathrm{~g}$., published as Trudy Instituta vostokovedeniia 36:81-110.

Gould, Rebecca. 2016. Writers and Rebels: The Literature of Insurgency in the Caucasus. New Haven, CT: Yale University Press.

Gould, Rebecca. 2013. "The Death of Caucasus Philology: Towards a Discipline beyond Areal Divides." Iran and the Caucasus 17:275-293.

Grant, Bruce. 2006. Review of Tribal Nation: The Making of Soviet Turkmenistan, by Adrienne Lynn Edgar. The Journal of Modern History 78 (3): 783-785.

Gundogdyev, Ovez. 2012. Turkmeny i narody mira: etnicheckie i kul'turnye sviazi [The Turkmen and the peoples of the world: Ethnic and cultural ties]. Ashkhabad: Turkmenskaia gosudarstvennaia izdatel'skaia sluzhba.

Güzel, Hasan Celâl, Kemal Çiçek, and Salim Koca, eds. 2002. Türkler [The Turks]. 21 vols. İstanbul: Yeni Türkiye Yayınları.

Gylychdurdyev, A. 1967. Magtymgulynyng estetiki garaiyshlary ve khazirki zaman = Esteticheskie vzgliady Makhtumkuly $i$ sovremennost' [The aesthetic views of Magtymguly and modernity]. Ashgabat: Ylym.

Husic, Geoff. 2017. "Using OCLC WorldCat Language Indexes to Quantify Slavic and Eurasian Language Collections and Answer Complex Bibliographic Questions.” Slavic \& East European Information Resources 18 (3-4): 109-127.

Iazberdiev, Almaz. 2001. Staropechatnye turkmenskie knigi: problemy sobiraniia, bibliografirovaniia $i$ izucheniia [Early Turkmen books printed with movable type: Problems of collection, compilation of bibliographies, and study]. Moskva: Orient-Press.

Iazberdiev, Almaz. 1993. Izdatel'skoe delo $v$ dorevoliutsionnom Turkmenistane [Publishing activity in prerevolutionary Turkmenistan]. Ashgabat: Ylym.

Iazberdyev, Almaz, comp. 1981. Arap grafikasynda neshir edilen turkmenche kitaplar = Turkmenskaia kniga na arabskoi grafike [Turkmen books in Arabic script]. Ashgabat: Ylym.

Irazek, H., and Vazgen Ghukasyan. 1986. Patmut'iun hndkahay tpagrut'ean [A history of Indian-Armenian printing]. Ant'ilias: Hratarakut'iun Kat'oghikosut'ean Hayots' Metsi Tann Kilikioy.

Isaacs, Rico, and Abel Polese. 2015. "Between 'Imagined' and 'Real' Nation-Building: Identities and Nationhood in Post-Soviet Central Asia.” Nationalities Papers 43 (3): 371-382.

Isaev, Amirkhan Amirkhanovich. 1989. Katalog pechatnykh knig i publikatsii na iazykakh narodov Dagestana: dorevoliutsionnyi period [A catalog of printed books and other publications in the languages of the peoples of Daghestan: The prerevolutionary period]. Makhachkala, Russia: IIIaL im. G. Tsadasy.

Isaev, Amirkhan Amirkhanovich. 2012. Katalog arabograficheskikh pechatnykh knig na darginskom i kumykskom iazykakh 1919-1930 godov [A catalog of Arabic-script printed books in the Dargwa and Kumyk languages, 1919-1930]. Makhachkala: Institut Istorii, Arkheologii i Etnografii Dagestanskogo Nauchnogo Tsentra Rossiiskoi Akademii Nauk.

Kadyrov, Shokhrat. 2001-2015. Rossiisko-Turkmenskii istoricheskii slovar' $v$ dvukh tomakh [A Russian-Turkmen historical dictionary in two volumes]. Bergen, Norway: Biblioteka al'manakha "Turkmeny," 2001 (v. 1) and Moskva: Institut Vostokovedeniia RAN, 2015 (v. 2).

Kasinec, Edward. 2008. "Yudin's Books in America: A View from the 21st Century." Slavic \& East European Information Resources 9 (2): 115-126.

Kemper, Michael. 2010. “An Island of Classical Arabic in the Caucasus: Dagestan.” In Exploring the Caucasus in the 21st Century: Essays on Culture, History and Politics in a Dynamic Context, edited by Françoise Companjen, Laszlo Maracz, and Lia Versteegh, 63-89. Amsterdam: Pallas.

Kemper, Michael, Amri Shikhsaidov, and Natalya Tagirova. 2002. “The Library of Imam Shamil.” The Princeton University Library Chronicle 64 (1): 121-140. 
Kirchanov, Maxim. 2010. "Turkmen Nationalism Today: Political and Intellectual Mythologemes." Central Asia and the Caucasus 11 (1): 52-63.

Khachatrian, Hayk. 1984. "Matrasi Tbagratan patmut'yunits" [The history of the Madras Printing House]. Lraber Hasarakakan gitut'ynneri 3:41-50.

Khalid, Adeeb. 2019. Review of Learning to Become Turkmen: Literacy, Language and Power, 1914-2014, by Victoria Clement. Russian review 78 (2): 347-348.

Knizhnaia Palata RSFSR. 1928. Knizhnaia letopis' Gosudarstvennoi Tsentral'noi Knizhnoi Palaty RSFSR: spetsial'nyi vypusk [The chronicle of books of the Central State Book Chamber of the RSFSR: special issue]. No. 3.

Kurbanov, Andrei Vasil'evich. 1995. Stavropol'skie turkmeny: Istoriko-etnograficheskie ocherki [The Stavropol' Turkmen: Historical-ethnographic essays]. Sankt-Peterburg: Izd. Otd. Iazykovogo tsentra SPbGU.

Kurenov, Sapar. 1962. Stavropol' Turkmenleri khem-de olaryng medeni bailygy [The Stavropol' Turkmen and their cultural riches]. Ashgabat: Turkmenistan Dovlet Neshiriaty.

Kürenov, Sapar. 1995. Kafkasya Oğuzları, veya türkmenleri: çovdurlar, igdirler, söyüncacılar [The Oghuz of the Caucasus, or the Turkmen: Çovdurs, İgdirs, and Söyüncacis]. Translated by Ali Duymaz. Kültür serisi 90. İstanbul: Ötüken.

Kuvadova, M., V. Panova, and A. Pirliev, comps. 1965. Sovet Turkmenistanyng kitaplary: jemleiji bibliografiia, 1920-1960: Birinji kitap = Kniga Sovetskogo Turkmenistana: svodnaia bibliografiia, 1920-1960: kniga pervaia [The book in Soviet Turkmenistan: a union bibliography, 1920-1960: Book 1]. Ashgabat: Turkmenistan.

Leich, Harry. 2008. “'So Ample a Collection, So Well Balanced': The Yudin Collection at the Library of Congress.” Slavic \& East European Information Resources 9 (2): 127-142.

Library of Congress. 2012. ALA-LC Romanization Tables: Kazakh (in Arabic script). https://www.loc.gov/catdir/cpso/roman ization/kazakh.pdf. (Accessed February 10, 2020.)

Library of Congress. 2017. ALA-LC Romanization Tables: Uzbek. https://www.loc.gov/catdir/cpso/romanization/uzbek.pdf. (Accessed February 10, 2020.)

Maghsoudi, Manizheh. 1987. “L'organisation sociale des Turkmène Yomut: famillie et mariage." PhD diss., Université René Descartes.

Maichel, Karol, comp. 1966. Soviet and Russian Newspapers at the Hoover Institution: A Catalog. Hoover Institution Bibliographical Series 24. Stanford, CA: Hoover Institution on War, Revolution \& Peace.

Malashenko, Alexei V., and Aziza Nuritova. 2009. “Islam in Russia." Social research 76 (1): 321-358.

Marshall, Alex. 2010. The Caucasus under Soviet Rule. London: Routledge.

Meyer, James. 2014. Turks across Empires: Marketing Muslim Identity in the Russian-Ottoman Borderlands, 1856-1914. London: Oxford University Press.

Michaelson, Aaron. 1999. “The Russian Orthodox Missionary Society, 1870-1917: A Study of Religious and Educational Enterprise." PhD diss., University of Minnesota.

Najibullah, Farangis. 2019. "Escape from Turkmenistan: Almost 2 Million Have Fled, but the president Looks the Other Way." Radio Free Europe/Radio Liberty, June 8, 2019. https://www.rferl.org/a/escape-from-turkmenistan-almost-2-million-havefled-but-the-president-won-t-hear-of-it/29987972.html. (Accessed November 19, 2020.)

Nazarova, Z. A., ed. 1989. Periodicheskie izdaniia sovetskogo Turkmenistana, 1924-1984: gosudarstvennyi bibliograficheskii ukazatel' = Sovet Turkmenistanynyng periodiki neshirleri, 1924-1984: dovlet bibliografiiasynyng gorkezijisi [The periodical publications of Soviet Turkmenistan, 1924-1984: A national bibliographic guide]. Ashkhabad: Turkmenistan.

Navruzov, Amir Ramazanovich. 2011. “Baian al-khakaik': zhurnal uchenykh arabistov Dagestana pervoi treti XX veka” ['Bayan al-haqaiq': The journal of the Arabic scholars of Daghestan of the first third of the 20th century]. Islamovedenie 2011 (3): $82-93$.

Nurmemmet, Annaguli. 1996. Göroglu: Türkmen halk destani = Görogly: Türkmen halk dessany [Köroğlu: A Turkmen folk epic]. 8 vols. Ankara: Bilig Yayınları.

Öner, Kemal, and Näzik Nepesowa. 2005. Beýik Saparmyrat Türkmenbaşynyn paýtagty = Great Saparmyrat Turkmenbasy's Capital City. Istanbul: Akademi Production.

Osmanova, Milena. 2008. Katalog pechatnykh knig na arabskom iazyke, vypushchennykh dagestanskimi izdateliami $v$ Rossii i za rubezhom v nachale XX veka: RF IIAE DNTs RAN - F. 15, Op. 1, Fond M.-S. Saidova [A catalog of printed books in Arabic published by Daghestani publishers in Russia and abroad at the beginning of the 20th century: The M.-S. Saidov collection]. Makhachkala: Institut Istorii, Arkheologii i Etnografii Dagestanskogo Nauchnogo Tsentra Rossiiskoi Akademii Nauk.

Özdemir, Ali Rıza. 2014. Kayıp Türkler: etnik coğrafafya bakımından Kürtleşen Türkmen aşiretleri [Missing Turks: Turkmen clans that have become Kurdish in terms of ethnic geography]. Ankara: Kripto.

Pan'kov, I. P. 1960. Iz istorii stavropol'skikh turkmen i kalmykov v XVII-XVIII vekakh: novye materialy [From the history of the Stavropol' Turkmen and Kalmyks in the 17th-18th centuries: New materials]. Chardzhou: Turkmenskii gosudarstvennyi pedagogicheskii institute imeni V. I. Lenina.

Pavković, Aleksandar, Halyna Koscharsky, and Adam Czarnota, eds. 1995. Nationalism and Postcommunism: A Collection of Essays. Aldershot: Dartmouth.

Perović, Jeronim. 2015. Der Nordkaukasus unter russischer Herrschaft: geschichte einer Vielvölkerregion zwischen Rebellion und Anpassung. Köln: Böhlau Verlag. 
Peyrouse, Sebastien. 2007. Turkménistan: un destin au carrefour des empires. Paris: Éditions Belin.

Peyrouse, Sebastien. 2012. Turkmenistan: Strategies of Power, Dilemmas of Development. Armonk, NY: M. E. Sharpe.

Polese, Abel, and Slavomir Horák. 2015. "A Tale of Two Presidents: Personality Cult and Symbolic Nation-Building in

Turkmenistan.” Nationalities Papers 43 (3): 457-478.

Pollock, Sean. 2006. "Empire by Invitation? Russian Empire-Building in the Caucasus in the Reign of Catherine II." PhD diss., Harvard University.

Poullada, S. Peter. 2018. Russian-Turkmen Encounters: The Caspian Frontier before the Great Game. Translated by Claora E. Styron. International Library of Central Asian Studies 9. London: I. B. Tauris.

Radio Free Europe/Radio Liberty. 2020. Marsho Radio. https://www.radiomarsho.com. (Accessed December 14, 2020.)

Reiss, Charles A. 1983. “The History of the Kalmyk Khanate to 1724." PhD diss., Indiana University.

Rezvan, E. A. 2016. "Salary Kitaia” [The Salars of China]. In Turkmeny, edited by Nadezhda Anatol'evna Dubova, 504-521. Moskva: Nauka.

Roberts, Sean. 1998. “The Uighurs of the Kazakstan Borderlands: Migration and the Nation.” Nationalities Papers 26 (3): 511-530.

Rossiiskaia Natsional'naia Biblioteka. 1997a. Katalog literatury na ingushskom yazyke [Catalog of literature in the Ingush language]. New York: Norman Ross.

Rossiiskaia Natsional'naia Biblioteka. 1997b. Katalog literatury na lezginskom yazyke [Catalog of literature in the Lezgi language]. New York: Norman Ross.

Rossiiskaia Natsional'naia Biblioteka. 1997c. Katalog literatury na nogaiskom yazyke [Catalog of literature in the Nogai language]. New York: Norman Ross.

Rossiiskaia Natsional'naia Biblioteka. 1998a. Katalog literatury na chechenskom yazyke [Catalog of literature in the Chechen language]. New York: Norman Ross.

Rossiiskaia Natsional'naia Biblioteka. 1998b. Katalog literatury na kumykskom yazyke [Catalog of literature in the Kumyk language]. New York: Norman Ross.

Rossiiskaia Natsional'naia Biblioteka. 1998c. Katalog literatury na turkmenskom yazyke [Catalog of literature in the Turkmen language]. New York: Norman Ross.

Rousselot, Hélène. 2015. "Construction du secteur des hydrocarbures et évolution politique au Kazakhstan et Turkménistan: indigénisation et rente 1919-2002.” PhD diss., École des hautes études en sciences sociales (Paris).

Russian National Library. 1994. Odnodnevnye gazety SSSR, 1917-1984 [One-day newspapers of the USSR, 1917-1984]. 46 reels. New York: Norman Ross.

Şahin, Savaş. 2015. "Stavropol Türkmenlerinin Tarih, Kültür, Dil ve Edebiyatları Hakkında” [On the history, culture, language and literature of the Stavropol' Turkmen]. Yeni Türkiye: "Kafkaslar" Özel sayısı 10:459-471.

Samoilovich, Aleksandr Nikolaevich. 1913. "Sredi stavropol'skikh turkmenov i nogaitsev i u krymskikh tatar: otchet o komandirovke v 1912 g." [Among the Stavropol' Turkmen and Nogais and with the Crimean Tatars: A report of a 1912 expedition]. Izviestiia Russkago komiteta dlia izucheniia Srednei $i$ Vostochnoi Azii $v$ istoricheskom, lingvisticheskom $i$ etnograficheskom otnosheniiakh, seriia II (2): 54-74.

Sergievskaia, I. S., G. Kh. Tantasheva, and B. Saatova, comps. 1962. Ukazatel' literatury na dunganskom, karachaevobalkarskom i checheno-ingushskom iazykakh, izdannoi v Kirgizii, 1930-1960 gg. [An index of literature in the Dungan, Karachai-Balkar and Chechen-Ingush languages published in Kyrgyzstan, 1930-1960]. Frunze: Kirgiz. gos. knizhnaia palata.

Shcheglov, I. L. 1910-1911. Trukhmeny i nogaitsy Stavropol'skoi gubernii: Sviedieniia o khoziaistvie osiedlykh i kochuiushchikh inorodtsev, russkikh krest'ian i khutorian-ovtsevodtsov v trukhmenskoi i achikulakskoi stepi Stavropol'skoi gubernii [The Trukhmen and Nogais of Stavropol' Province: Information about the economy of the settled and nomadic natives, Russian peasants and farmer-shepherds of the Trukhmen and Achikulak steppes of Stavropol' Province]. 4 vols. Stavropol': Tipografiia gubernskago pravleniia.

Seregny, Scott J. 2001. "A Wager on the Peasantry: Anti-zemstvo Riots, Adult Education and the Russian Village during World War I: Stavropol' Province.” The Slavonic and East European Review 79 (1): 90-126.

Shikhaliev, Shamil' Shikhalievich. 2010. “'Al-dzhavab as-sakhikh li-l-akh al-musallakh' 'Abd al-Khafiza Okhlinskogo” ['Abd al-Khafiz Okhlinskii's 'Trustworthy answers to a devout brother']. In Dagestan i musul'manskii Vostok: Sbornik statei = Daghestan and the Muslim East: Studies on History and Sources in Honor of Amri Shikhsaidov, edited by Alikber K. Alikberov and Vladimir O. Bobrovnikov, 324-340. Moskva: Mardzhani.

Shikhmuradov, Boris, and Murad Esenov. 2002. "'Esli ty skazhesh', kto tvoi predvoditel'...': GATM - est' takaia organizatsiia” ["If you tell me who your leader is": HATW - Such an organization does exist]. Centrasia, March 27, 2002. https:// centrasia.org/newsA.php?st=1017181080. (Accessed November 20, 2020.)

Shikhsaidov, Amri R., Michael Kemper, and Al'frid K. Bustanov, eds. 2012. Uslada umovv biografiiakh dagestanskikh uchenykh = A Journey of the Minds, through the Biographies of the Islamic Scholars of Daghestan. Moskva: Mardzhani.

Shykhmyradov, B. O., et al., eds. 1993. Turkmen khalkynyng gelip chykyshynyng dunia iairaishynyng ve onung dovletining tarykhynyng problemalary: khalkara ylmy konferentsiianyng dokladlarynyng ve khabarlarynyng tezisleri, Ashgabat, 1993 i. 25-26 oktiabr' = Problemy istorii proizkhozhdeniia, migratsii turkmenskogo naroda i ego gosudarstvennosti [Problems of the history of the origins, migrations, and statehood of the Turkmen people: Proceedings of the international scholarly conference, Aşgabat, 25-26 October 1993]. Ashgabat: RUKh neshiriaty. 
Smith, M. 2005. Review of Tribal Nation: The Making of Soviet Turkmenistan, by Adrienne Lynn Edgar. Slavic Review 64 (4): 900.

Soegov, Muradgeldi. 2014. "Politicheskii deiatel' netraditsionnoi orientatsii: o zhizni i deiatel'nosti Makhmuda Tumailova" [An unconventional politician: On the life and activities of Mahmyt Tumaýylow]. Turkologiia: Qozha Akhmet Iasaui Khalyqaralyq qazaq-turik universitetining zhurnaly 68:103-110.

Staudinger, Katrin. 2012. Freie Nomaden, edle Räuber, skrupellose Sklavenjäger: zur Darstellung von Turkmenen in Reiseberichten aus dem 19. Jahrhundert. Wien: Verlag der Österreichischen Akademie der Wissenschaften.

Sunderland, Willard. 2004. Taming the Wild Field: Colonization and Empire on the Russian Steppe. Ithaca, NY: Cornell University Press.

Suruç, Salyh. 1999. Älemleriñ serweri pygamberimiziñ ömri: ikinji kitap [The life of Our Prophet, Messenger of God: Book one]. Ankara: Goktash.

Tadzhiev, Gapur. "Rod turkmen ne issiaknet!" [The Turkmen people shall not die out!]. Gündogar, May 22, 2009. http:// www.gundogar.org/?0221047857000000000000011000000. (Accessed November 20, 2020.)

Tahirova, Natalya. 2002. "Imam Shamil's Manuscripts in the Collections of Princeton University (from the History of Daghestan's Book Culture in the 19th Century)." Central Asian survey 21 (3): 325-332.

Tsutsiev, Artur. 2006. Atlas etnopoliticheskoi istorii Kavkaza, 1774-2004 [An atlas of the ethnopolitical history of the Caucasus, 1774-2004]. Moskva: Evropa.

Tulu, Sultan. 2005. Asli-Kerem hikâyesinin Türkmence varyantı: giriş, metin, sözlük [The Turkmen variant of the Asli-Kerem story: Introduction, text, dictionary]. Ankara: Urün Yayınları.

Türkmenistanyň Prezidentiniň Arhiw gaznasy. 2007. S. A. Nyýazow--Beýik Saparmyrat Türkmenbaşy: gysgaça terjimehal = S.A. Niiazov--Velikii Saparmurat Turkmenbashi: kratkaia biografiia [S. A. Nyýazow-the Great Saparmyrat Turkmenbashy: A brief biography]. Aşgabat: Türkmen döwlet nesriýat gullugy.

Turkmenistanyng Dovlet kitap palatasy. 1991-. Turkmenistanyng metbugat letopisi: Dovlet bibliografiiasynyng gorkezijisi = Letopis' pechati Turkmenistana: gosudarstvennyi bibliograficheskii ukazatel' [The publishing chronicle of Turkmenistan: A national bibliographic guide]. Ashgabat: Knizhnaia palata Turkmenistana.

UNPO (Unrepresented Nations and Peoples Organization). 2015. Member Profile: Iraqi Turkmen (Iraqi National Turkmen Party). March 2015. https://unpo.org/downloads/2360.pdf. (Accessed November 22, 2020.)

Vachagaev, M. M. 2018. Soiuz gortsev Severnogo Kavkaza i Gorskaia Respublika: istoriia nesostoiavshegosia gosudarstva [The Union of the Mountaineers of the North Caucasus and the Mountain Republic: The history of a nonexistent state]. Moskva: Tsentrpoligraf.

Veliev, Baba, comp. 1980. Stavropol' turkmenlerining dessanlary = Destany stavropol'skikh turkmen [Epic poetry of the Stavropol' Turkmen]. Ashgabat: Ylym.

Veliev, Baba and Jumakhaset Yliasov, comps. 1982. Stavropol' turkmenlerining nakyllary [Sayings of the Stavropol' Turkmen]. Ashgabat: Ylym.

Volodin, A. 1908a. “Trukhmenskaia step' i trukhmeny” [The Trukhmen Steppe and the Trukhmen]. Sbornik materialov dlia opisaniia mestnostei i plemen Kavkaza 38, Otdiel I, 1-98 of the second subsection.

Volodin, A. 1908b. "Iz trukhmenskoi narodnoi poezii" [Selections from Trukhmen folk poetry]. Sbornik materialov dlia opisaniia mestnostei i plemen Kavkaza 38, Otdiel II, final subsection, 49-57.

Waley, Muhammad Isa. 1993. Periodicals in Turkish and Turkic Languages: A Union List of Holdings in U.K. Libraries. Oxford: Middle East Libraries Committee.

Wixman, Ronald. 1980. Language Aspects of Ethnic Patterns and Processes in the North Caucasus. The University of Chicago Department of Geography Research Paper no. 191. Chicago: Department of Geography.

Wixman, Ronald. 1984. The Peoples of the USSR: An Ethnographic Handbook. Armonk, NY: M. E. Sharpe.

Yazberdiyev, Almaz. 2005. Doğu'da matbu yayınların tarihi: 1802-1917 Arab alfabeli Türkmen kitapları kataloğu [The history of print publications in the East: A catalog of Turkmen books in Arabic script, 1802-1917]. Translated by Ahmet R. Annaberdiyev. İnceleme-araştırma serisi 34. İstanbul: Kaknüs Yayınları.

Yliasov, Jumakhaset. Foreword by Shabanaly Jumaev. 1994. Stavropoldan salam: goshgular [Hello from Stavropol': Poems]. Ashgabat: Ylym.

Cite this article: Condill, K. 2021. Comparative Nationalisms and Bibliographic Black Holes: The Case of the Turkmen of the North Caucasus. Nationalities Papers 49: 1150-1177, doi:10.1017/nps.2020.85 